\title{
Terrestrial Mammal Feces: a Morphometric Summary and Description
}

\author{
Marcia Chame
}

Laboratório de Ecologia, Departamento de Endemias, Escola Nacional de Saúde Pública-Fiocruz, Rua Leopoldo Bulhões 1480 , 21240-210 Rio de Janeiro, RJ, Brasil

The study of feces of terrestrial mammals brings out biological and ecological data such as the species presence, diet, behaviour, territory, parasitic fauna, and home-range use, which can be applied for conservation projects and support paleoecological research that use coprolites as the main source of study. Although the new biotechnological techniques allow more accurate data, the diagnosis based on morphometric analyses permits the primary identification of the taxonomic group origin to support the best choice of subsequent analyses. We present the compilation list of fecal shape and measurements available in the literature published in North America, Eastern and Southern Africa, Europe, and new data from Brazil. Shape and diameters are the best characteristics for taxonomic identification. Feces were assembled in 9 groups that reflect the Order, sometimes the Family, and even their common origin.

Key words: feces - coprolites - terrestrial mammals - fauna

Tracking is probably the oldest science (Liebenberg 1990). By looking for signs left by animals we learn to observe useful details to hunt them or to avoid them. Tracking reveals the age of marks left by animals and the natural behaviour of animals without the influence of the observer (Wemmer et al. 1996). As a non-invasive method, it constitutes an important tool for studying threatened species or animals difficult to observe and trap. It can be applied as well for studying rare and nocturnal animals. Although it requires observers who are well trained with sharp sensitivity, its low cost and accessible technology turn tracking into a good choice for field studies.

Besides the observer abilities, some other factors influence the find of marks and signs left by animals. Soil characteristics, vegetation, and local climate determine sign and mark conditions. Sandy and loamy soils preserve better footprints than soft soils with thick organic material of superposed layers, and stony areas. However, stony areas, dry ecosystems, and frozen ecosystems provide the best preservation for feces (Bang \& Dahlström 1975). On the other hand, it is not easy to identify signs in areas where animals have high demographic densities.

Feces are the most evident and most easily recognizable sign (Liebenberg 2000). However, the rarity of some species difficult the observation, as well as others factors like, the presence of buried feces or the behaviour of defecating inside the water or on the branches of the trees. For identification, the original fecal shape must be maintained. Several factors can corrode the original fecal shape through time. These factors include heat, desiccation, or fast decomposition in humid and rainy regions. Fragmentation by other animals such as dung beetles and termites, which frequently consume herbivorous feces, is

Fax: +55-21-2257.3946. E-mail: mchame@ensp.fiocruz.br Received 26 August 2002

Accepted 25 November 2002 also another factor that prevents fecal preservation (Stuart \& Stuart 1998). Feces can also be consumed by carnivores. For example spotted hyenas eat lion dung and fresh wild dog dung (Stuart \& Stuart 1998).

Droppings consist of partly digested material and undigested parts of animals and plants. Fecal components may include feathers, bones, teeth, claws, scales, arthropod chitin, seeds and plant tissues, pollen grains, as well as mucus, cells, and a significant amount of living and dead bacteria (Bang \& Dahlström 1975, Bjune 2000).

Mammal feces have a social communication role (Gorman \& Trowbridge 1989). When randomly deposited they show the individual or group home-range, as among American marsupials, lagomorphs, some ungulates, some rodents, and primates. They are used as territorial marks when deposited in small volumes in prominent places such as trail junctions, rocks, trunks, or termite nests. Feces are used as strategic sensorial marks by all Carnivora family species except Hyaenidae (Gorman \& Trowbridge 1989, Estes 1991, Romo 1995, Aragona \& Setz 2001). Some mammals defecate in discreet individual latrines as do hyaenas (Gorman \& Trowbridge 1989) and collared anteaters (Tamandua tetradactyla, Myrmecophagidae : Edentata) in the Brazilian Northeast (Chame 1988). Collective latrines are used by some ungulates, such as antelopes (Walker 1996), Hyrax spp (Kingdon 2001), and some procyonids (Page et al. 2001). Collective latrines can also be used for generations as in the case of Kerodon rupestris (Caviidae: Rodentia), an endemic species of the Brazilian semiarid region. Feces from this animal are found in rock-shelters and in the archaeological sites of the Serra da Capivara National Park (Ferreira et al. 1991, Araújo et al. 1993).

In the carnivores, the secretion produced by the anal gland adheres to the feces during defecation. The secretion of each species has a characteristic and complex odour and it supplies intra and interspecific information of an individual's territory, sex, reproductive state, and movements (Gorman \& Trowbridge 1989). The size and the amount of feces produced by each individual varies with age, the 
type of ingested food, and its absorption capacity (Bang \& Dahlström 1975). Size variation is more frequent among herbivores because of the alteration in the quality and amount of food ingested in different seasons. Size varies less among carnivores (Stuart \& Stuart, 1998). Food characteristics also affect fecal consistency. Fibrous plants may be the only food found during dry periods or in arid environments, so animals produce hard and more compact feces. During rainy periods or in tropical rainforest ecosystems, the larger consumption of green leaves, sprouts, and fruits produce soft, large, and aggregated feces.

Scatology is the science that studies feces (Seton, 1925) and since 1970s the number of studies in this area is increasing (Putman 1984, Halfpenny \& Biesiot 1986, Kohn 1997). Several types of information can be obtained from feces and their contents, including the identification of the animal (Seton 1925, Camardella et al. 2000), their activity centers (Walker 1996), diet composition (Johnson \& Hansen 1978, Johnson \& Aldred 1982, Emmons 1987, 1997, Inagaki \& Tsukahara 1993, Chinchilla 1997, Santos \& Hartz 1999, Kauhala \& Auniola 2001), seasonal diet changes (Corn \& Warren 1985, Aragona \& Setz 2001), inventory of prey species (Floyd et al. 1978, Emmons, 1987, Camardella et al. 2000), the role of seed dispersion (Fragoso \& Huffman 2000, Williams et al. 2000), health condition, and potential enteroparasitosis dynamics (Patton et al. 1986, Page et al. 2001). Researchers have been using feces counting methods for population estimation (Neff 1968). However, the effectiveness of this methodology is still controversial due to seasonal variation, the difficulty in estimating a daily defecation output, and predicting the time of fecal decomposition (Lancia et al. 1996, Patterson 1998).

Scatology developed from basic morphometric description to more sophisticated chemical analyses (Nagy \& Gilbert 1968, Johnson \& Carey 1979, Weaver \& Fritts 1979 , Weaver \& Hoffman 1979, Major et al. 1980, Danner \& Dodd 1982, Rollings et al. 1984, Fernández et al. 1997). Recently, the application of molecular biology techniques to the study of feces allowed new approaches for the management of threatened species (Reed et al. 1997). Through DNA recovered and identified from feces, it is possible to distinguish similar feces of sympatric carnivores (Farrel et al. 2000), population variation and biogeography of isolated ape groups in fragmented forests (Jensen-Seaman $\&$ Kidd 2001), and the variation in food behavior among individuals of the same species (Fedriani \& Kohn 2001).

Despite biotechnological progress, the basic initial diagnosis provided by morphometry and the assemblage of signs observed in the field determine the starting point for subsequent studies, and the choice of more sophisticated techniques. For paleoparasitological studies it is important to identify the zoological origin of coprolites. So, the study of fecal morphology is important for modern wildlife study and paleoecological coprolite study.

Presented here is a comprehensive summary of fecal morphometric data from bibliographical sources for conspicuous species of terrestrial mammals. These data are from North America, Central America and South America, Europe, and Southern Africa, and Eastern Africa. It also includes the results of my studies in Brazilian arid Northeast.

\section{MORPHOMETRIC CHARACTERISTICS OF TERRESTRIAL MAMMAL FECES}

Data presented here were obtained from scientific journals and also from field guides published by non-academic editors (Burt \& Grossenheider 1973, Murie 1974, Bang \& Dahlström 1975, Russo \& Olhausen 1987, Estes 1991, Walker 1996, Stuart \& Stuart 1996, 998, Lienbeberg 2000, Kingdon 2001).

The compiled data, presented in Tables I-IV and in the Figure allows the morphometric analysis and the identification of 9 similar fecal groups. Our groups are in accordance with Seton (1925) who emphasized that the form and the contents of feces are excellent guides for the diagnosis of each mammalian Order. They reflect their peculiar anatomy. Feces have a low value to the diagnosis at the Family level, and none at generic level. Seton (1925) presents the curious and seemingly contradictory statement that fecal shape is a valuable and auxiliary consideration in specific diagnosis, and that size and food contents can sometimes separate close related species (Chame 1991).

\section{GROUP I}

Cye Cylindrical feces (sausage-shaped), with sub-divisions, tapered at one of the extremities. Characteristic of the Carnivora Order.

The Felidae family feces can be identified by their compact form with well defined segments and one of the extremities especially tapered (Table I, II, III and Figure). Other families and subfamilies can be distinguished by the difference of diet remains, such as in pinnipeds and aquatic mustelids (Lutrinae), whose feces are only composed of fish, crustacean, and mollusc remains. Felid feces reflect strictly carnivorous diet. However, grass leaves ingested to aid hair elimination are also found. Fruit, seed, insect, crustacean, plant tissues, and shell fragments are commonly found in omnivorous canids, mustelids, viverids, and procyonids feces.

In North America, felid feces with diameters larger than $2.5 \mathrm{~cm}$ can be identified to jaguar (Panthera onca) and puma (Puma concolor). Feces with smaller diameters are assigned to other felid species (Johnson et al. 1984). In Brazilian Northeast a diameter larger than $2.1 \mathrm{~cm}$ is enough to separate the great felids ( $P$. onca and $P$. concolor) from the small felids (Leopardus tigrinus, Leopardus wiedii, Leopardus pardalis, and Herpailurus yaguaroundi) $(\mathrm{P}<$ 0.0001 , Chame 1988). Morphometric patterns can not distinguish puma from jaguar feces, and both species are sympatric (Emmons 1997).

In Costa Rica, Chinchilla (1997) showed that ocelot feces (Leopardus pardalis) have a significantly smaller diameter $(\chi=2.26 \pm 2.46 \mathrm{~cm}, \mathrm{n}=15)$ than jaguar $(\chi=3.15$ $\pm 1.82 \mathrm{~cm}, \mathrm{n}=16)$ and puma $(\chi=2.92 \pm 1.09 \mathrm{~cm}, \mathrm{n}=9)(\mathrm{P}<$ $0.05)$. As in the other regions of the Americas, the measurements do not distinguish the great feline feces. In similar studies in Peru, Romo (1995) found that the puma fecal diameter exceeded $2.5 \mathrm{~cm}$, whereas Andean Fox (Pseudalopex culpaeus) varied from 1.7 to $2.2 \mathrm{~cm}$, and mountain cat feces (Leopardus colocolo) varied from 1.3 to $1.6 \mathrm{~cm}$. 
Studies of sympatric North American canids show that feces with diameters larger than $3 \mathrm{~cm}$ can be identified as of wolf (Canis lupus), and smaller, similarly shaped feces were from coyote (Canis latrans). Only $4.9 \%$ of coyote feces are misdiagnosed as wolf feces (Waever \& Fritts 1979). However, with chemical and molecular analysis it is possible to identify coyote, fox and bobcat feces (Stokes $\&$ Stokes 1986). In Europe, the Gray Wolf feces (Canis lupus) vary from $10-15 \times 2.5-3 \mathrm{~cm}$ and the Red Fox feces (Vulpes vulpes) from 8-10 × $2 \mathrm{~cm}$ (Table III). Thus, feces from these animals can be identified by morphometry (Bang \& Dahlström 1975).

In Brazil the maned-wolf (Chrysocyon brachyurus) is the larger canid species. Its feces have diameters larger than $2.5 \mathrm{~cm}$, and also an characteristic odour and texture. Furthermore, its feces contain fruit remains which are distinctive to this animal (Motta-Júnior et al. 1999, Aragona \& Setz 2001). In central Brazil (Serra da Canastra National Park) we found a sample of maned-wolf feces with a diameter of $4.5 \mathrm{~cm}$, considerably larger than cougar and jaguar feces. Other Brazilian canids are smaller, so it is easy to identify maned-wolf feces (Dalponte 1997) (Table IV).

In Africa the great diversity of medium and large carnivores do not allow a feces morphometric diagnosis criteria (Table I).

Feces of large carnivores can sometimes be totally white as happens with jaguar and puma in America, lion (Panthera leo) and hyenas in Africa, and wolf (Canis lupus) in Europe and North America. White feces are a result of high calcium content as a consequence of bone ingestion (Bang \& Dahlström 1975, Chame 1991). They

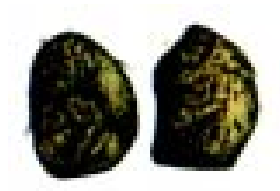

Tayassu tajacu

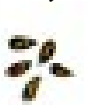

Oryzomys subflavus

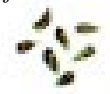

Calomys Callosus

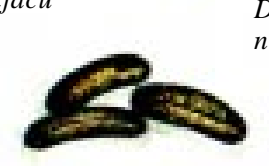

Kerodon rupestris

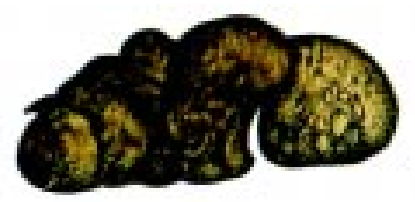

Dasypus

novemcinctus

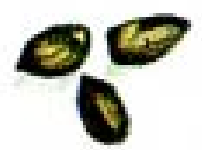

Mazama gouazoubira can be also be completely black as lion feces, due to the great amount of blood ingested (Lienbenberg 2000).

\section{GROUP II}

Well rounded little and single pellets deposited in small patches or in large accumulations. This kind of feces includes the order Lagomorpha (hares and rabbits) and some ungulates, as the hyrax (Procavidae: Hyracoidea), and antbear (aardvark) (Orycteropodidae: Tubilidentata) (Table I, II, III). Antbear is the closer protoungulate to modern species of hoofed ungulates, and has a common origin with tapirs, rhinos, hyraxes, elephants, and artiodactyles (Kingdon 2001).

In this group, shape and diet do not allow to identify the origin of the feces, except for Orycteropus afer (Aardvark) (Table I), a termite, ant, and larva consumer.

\section{GROUP III}

Single and cylindrical pellets. They present two round extremities, or with one extremity slightly tapered. This group includes all the rodents. These feces vary from very small, such as in Muridae and Sciuridae rats, to medium, such as in porcupine (Hystricidae in Africa and Erithizonthidae in America), gophers (Geomyidae) paca (Agoutidae), agouti (Dasyproctidae), and Castoridae (in Europe and North America).

In Northeastern Brazil, feces of Trichomys apereoides (Echymyidae), Oryzomys subflavus (Muridae: Sigmodontinae), Calomys callosus (Cricetidae), Galea spixi, and Kerodon rupestris (Caviidae) $(\mathrm{P}<0.0001)$ (Table IV) can be distinguished by diameter measurements (Chame 1988).

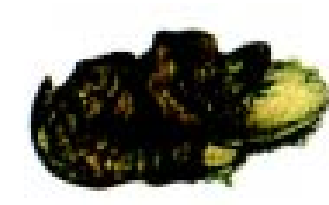

Alouatta caraya

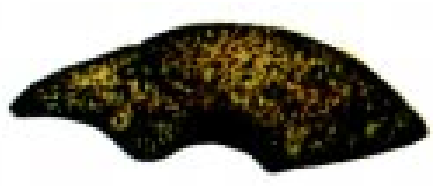

Tamandua tetradactyla

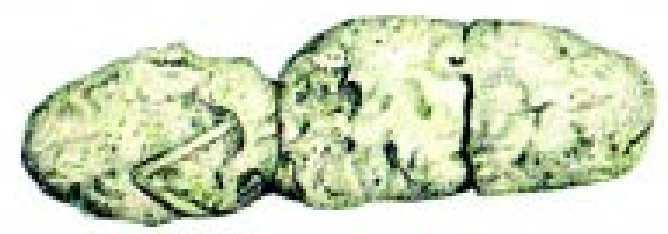

Panthera onca

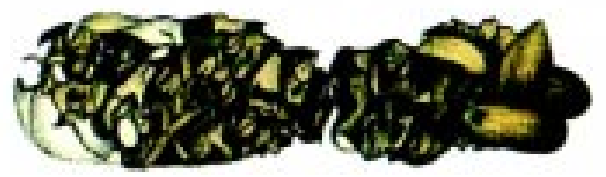

Cerdocyon thous

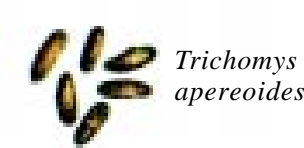

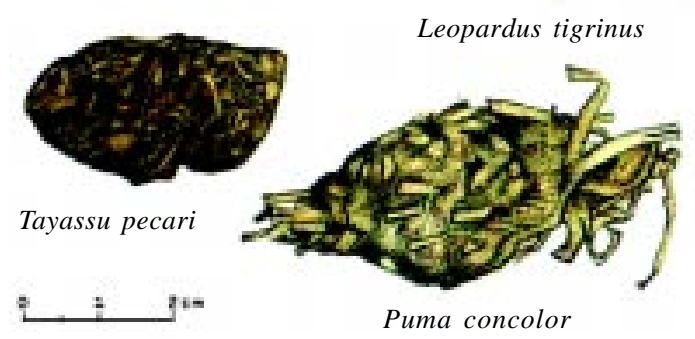

Feces' shape from Northeastern Brazilian Mammals 


\section{GROUP IV}

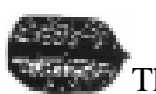

This group is related to Group III. Single pellets are cylindrical, inflected, and with the extremities usually round. However, what differentiates them from the others is a characteristic furrow along the length (coffee bean shape). This group includes the African rodents (great canerats) of the family Thrynomyidae (Thryonomys gregorianus and T. swinderianus) (Table I). This African rodent family is represented by fossils 20 million years old in North Africa. The family shows many similarities with certain current rodents of South America, especially Carterodon (Kingdon 2001). In Northeastern Brazil we found Kerodon rupestris and Galea spixii (Caviidae) feces that are also included in this group (Table IV, Figure). Both families belong to the guinea pig-type rodents (Caviomorpha), and have a common origin.

The feces of K. rupestris and G. spixii can be diagnosed accurately. $K$. rupestris feces present prominent furrow in the concave face and a diameter larger than 0.8 $\mathrm{cm}$. In G. spixii feces the furrow is in the convex part and the diameter is smaller than $0.8 \mathrm{~cm}$ (Table IV, Figure).

\section{GROUP V}

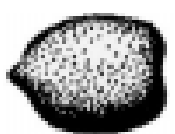

Cylindrical or rounded pellets usually pointed at one end and concave in the other extremity (Table I, II, III, Figure). This group includes all of Artiodactyles (Super Order Ungulata), except those of Bovini tribe (Bovinae) that includes the bisons, the buffalos and domestic cattle. They are well adapted to semi-arid environments (Kingdom 2001). The droppings of single pellets can be deposited in latrines, as for the rhinoceros (Walker 1996), and depending on fresh food available they can be condensed to form large soft and green patties.

The feces of two deer species from Brazilian semi-arid region (Mazama gouazoubira and Mazama americana) cannot be differentiated by the shape and size (Table I, II, IV), as observed also in similar species in Africa, North America and Europe.

\section{GROUP VI}

Flattened feces that accumulate in circular piles. The shape of this group is very familiar to people because it includes feces of domestic cattle, buffalo, and bison (Bovini: Bovinae). During dry seasons, and in dry environments, these feces are brittle and the number of piles are few. During humid periods, they are amorphous (Stuart \& Stuart 1996).

\section{GROUP VII}

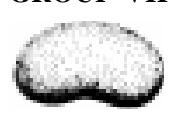

Single riniform (kidney-shaped) feces. This group just includes feces of the family Equinidae (Perissodactyla: Ungulata) and warthog (Phacochoerus africanus) (Suidae). They occur united, or in cake-like deposits in humid areas or during summer in temperate countries.

\section{GROUP VIII}

Big and cylindrical feces like bars that characterise large ungulates such as the elephants, hippopotamus, and rhinoceros. The two African species of rhinoceros use collective latrines which can be shared when they are in the same territory (Stuart \& Stuart 1998). Dung of the white rhinoceros (Ceratotherium simum) contains only grass, while black rhinoceros (Dicerus bicornis) is easily identified by its fibrous and woody contents (Walker 1996, Liebenberg 2000).

This group also includes South American anteaters (Myrmecophagidae: Xenarthra). Collared anteater feces (Tamandua tetradactyla) are cylindrical and continuous. They measure 1.8-8.1 x 1.1-2.8 cm and easily break when they fall on the ground. They are deposited close to shelters, in easily recognisable individual latrines. The surface is flat and ant and termite remains can be observed with naked eye. Although there are no morphometric studies of feces of other species of this family, it is possible that their size could be used to distinguish them. Giant anteater (Myrmecophaga tridactyla) is the larger species weighing from 22 to $39 \mathrm{~kg}$. The silky or pygmy anteater (Cyclopes didactylus) just weighs between 155 to $275 \mathrm{~g}$. Two other species have the same size but do not share the same geographical distribution (Emmons 1997). These species are T. tetradactyla (that weighs from 3.6 to $8.4 \mathrm{~kg}$ ) and the Northern tamandua (Tamandua mexicana).

\section{GROUP IX}

This group includes species, families, and orders for which feces are of mixed shape and size. Opossuns (Didelphidae: Marsupialia), primates, armadillos (Dasypodidae: Xenarthra) and insectivores (Insectivora) are included in this group. Feces are amorphously cylindrical or rounded, but without any common or possible specific characteristic to be attributed to any group. However, they can be identified when associated to other evidence such as footprints, other marks, or when there is a complete knowledge of the local fauna of the region.

Usually, primate feces can be identified if the feeding sites are known such as with capuchin monkey studies (Cebus apella, Cebidae) in southern Brazil (Pizo \& Oliveira 1999), and black-howler-monkeys (Alouatta caraya, Atelidae) in the Brazilian Northeast (Chame \& Olmos 1997).

\section{FINAL CONSIDERATIONS}

Nine groups can be characterised by fecal morphometry, and the patterns of shape and size of the terrestrial mammal feces are sufficiently consistent to group them (Bang \& Dahlström 1975). Although the size of the feces varies with individual animal age, as well as food habits, a size limit can be standardised and attributed to them. Particularly, in my studies conducted in the Northeast of Brazil, the shape and diameter of the feces are a better specific indicators than length. Shape can be identified as the first indicator for the diagnosis of the fecal origin, cor- 
roborating the statements of Seton (1925). The statistical analysis of measurements can distinguish species of the same group, as in rodents of the Northeast of Brazil (Chame 1988). When the diet is well known for a determined area, it can be an important factor to distinguish species, as in the case of the African rhinoceros and South American canids (Chame 1991, Motta-Júnior et al. 1996, Dalponte 1997, Aragona \& Setz 2001).

The groups of feces identified in this work suggest that the morphology of the feces may reflect a species phylogeny, corroborating paleontological data about the evolution and radiation of the mammals.

It is expected that the definition of morphometric patterns to identify terrestrial mammal feces can be used not only for the progress of field studies of current fauna, but also to stimulate biomolecular studies based on feces for paleoecological, and paleoparasitological studies (Chame et al. 1991, Araújo et al. 2000) that use coprolites as a primary source of investigation.

As the study of the feces and coprolites starts in the field, with the tracking animals or with the archaeological excavations, it is the observer's acuity and sharpness in the gathering the largest amount of information left by the animals in nature, together with laboratory results, that makes it possible to rebuild movements, ecosystems, and biological and ecological relationships. In essence, it allow us to determine what has happened when there were no observers present.

\section{ACKNOWLEDGMENTS} Guides.

To Gabriela Landau Remy for providing the African Field

\section{REFERENCES}

Aragona M, Setz EZ 2001. Diet of the maned wolf, Chrysocyon brachyurus (Mammalia: Canidae), during wet and dry seasons at Ibitipoca State Park, Brazil. J Zool 254: 131-136.

Araujo AJG, Ferreira LF, Camillo-Coura L, Gonçalves MLC 2000. Parasitos, parasitismo e paleoparasitologia. An Acad Nac Med Rio de Janeiro 160: 20-27.

Araújo AJG, Rangel A, Ferreira LF 1993. Animal parasitic infection and climate change in Northeastern Brazil. Mem Inst Oswaldo Cruz 88: 577-579.

Bang P, Dahlström P 1975. Huellas y Señales de los Animales de Europa, Omega, Barcelona, 239 pp.

Bujne AE 2000. Pollen analysis of faeces as a method of demonstrating seasonal variations in the diet of Svalbard reindeer (Rangifer tarandus platyrhynchus). Polar Res 19: 183192.

Burt WH, Grossenheider RP 1973. A Field Guide to the Mammals, 3rd ed., Houghton Miffin, Boston, 289 pp.

Camardella, AR, Abreu MF, Wang E 2000. Marsupials found in felids scats is southern Brazil, and a range extension of Monodelphis theresa. Mammalia 64: 379-382.

Chame M 1988. Estudo Comparativo das Fezes e Coprólitos não Humanos da Região Arqueológica de São Raimundo Nonato, Sudeste do Piauí, MSc Thesis, MN/UFRJ, 134 pp.

Chame M, Olmos F 1997. Two Howler species in Piauí? Neotrop Primates 5: 74-77.

Chame M, Ferreira LF, Araújo AJG, Confalonieri U 1991. Experimental paleoparasitology: an aproach to the diagnosis of animal coprolites. Paleopathol News 76: 7-9.

Chinchilla FA 1997 La dieta del jaguar (Panthera onca), el puma (Felis concolor) y el manigordo (Felis pardalis) (Carnivora:
Felidae) en el Parque Nacional Corcovado, Costa Rica. Rev Biol Trop 45: 1223-1229.

Corn JL, Warren RJ 1985. Seasonal food habits of collared peccary in south Texas. J Mammal 66: 155-159

Dalponte JC 1997. Diet of the hoary fox, Lycolopex vetulus, in Mato Grosso, Central Brazil. Mammalia 61: 537-547

Danner DA, Dood N 1982. Comparison of coyote and gray fox scat diameters. $J$ Wildl Mgmt 46: 240-241.

Emmons LH 1987. Comparative feeding ecology of felids in a Neotropical Rainforest. Behav Ecol Sociobiol 20: 271-283

Emmons LH 1997. Neotropical Rainforest Mammals. A Field Guide, 2nd ed., The Univ. Chicago Press, Chicago, 307 pp.

Estes RD 1991. The Behaviour Guide to African Mammals, Univ. California Press, California, 611 pp.

Farrel LE, Roman J, Sunquist ME 2000. Dietary separation of sympatric carnivores identified by molecular analysis of scats. Mol Ecol 9: 1583-1590.

Fedriani JM, Kohn MH 2001. Genotyping faeces links individuals to their diet. Ecol Letters 4: 477-485.

Fernández GJ, Corley JC, Capurro AF 1997. Identification of cougar and jaguar faeces through bile acid chromatography. $J$ Wildl Mgmt 61: 506-510.

Ferreira LF, Araújo AJG, Confalonieri EU, Chame M, Gomes, DC 1991. Trichuris eggs in animal coprolites dated from 30.000 years ago. J Parasitol 77: 491-493.

Floyd TJ, Mech LD, Jordan PA 1978. Relating wolf scat content to prey consumed. J Wildl Mgmt 42: 528- 532.

Fragoso JMV, Huffman JM 2000. Seed-dispersal and seedling recruitment patterns by last Neotropical megafaunal element in Amazon, the tapir. J Trop Ecol 16: 369-385.

Gorman ML, Trowbridge BJ 1989. The role odor in the social lives carnivores. In JL Gittleman, Carnivore Behaviour, Ecology and Evolution, Chapman \& Hall Ltd, New York, p. $57-88$.

Halfpenny J, Biesiot 1986. A Field Guide to Mammal Tracking in North America, 2nd ed., Johnson Publishing, New york, $161 \mathrm{pp}$.

Inagaki H, Tsukahara T 1993. A method of identifying chimpanzee hairs in lion feces. Primates 34: 109-112.

Jensen-Seaman MI, Kidd KK 2001. Mitocondrial DNA variation and biogeography of eastern gorillas. Mol Ecol 10: 2241-2247.

Johnson MK, Aldred DR 1982. Mammalian prey digestibility by bobcats. $J$ Wildl Mgmt 46: 530 .

Johnson MK, Carey AB 1979. Porcupine pellet pH, color and composition. Southwestern Nat 24: 554-555.

Johnson MK, Hansen RM 1978. Estimating dry weights per occurrence for taxa in coyote scats. J Wildl Mgmt 42: 913915.

Kauhala K, Auniola M 2001. Diet of raccoon dogs in summer in the Finnish archipelago. Ecography 24: 151-156.

Kingdon J 2001. The Kingdon Field Guide to African Mammals, Academic Press, New York, 476 pp.

Kohn MH, Wayne, RK 1997. Facts from faeces revisited. Trends Ecol Evol 12: 223-227.

Lancia RA, Nichols JD, Pollock KH 1996. Estimating the number of animals in wildlife populations. In TA Boukhout, Research and Management Techniques for Wildlife and Habitats, The Wildlife Soc, Washington, p. 215- 153.

Liebenberg L 1990. The Art of Tracking: the Origin of Science, David Philip Publishers, Cape Town, 176 pp.

Liebenberg L 2000. Tracks and Tracking in Southern Africa, Struik Publishers, Cape Town, 144 pp.

Major M, Johnson MK, Davis WS, Kellog TF 1980. Identifying scats by recovered of bile acids. J Wildl Mgmt 44: 290293.

Motta-Junior JC, Talamoni SA, Lombardi JA, Simokomaki K 
1996. Diet of maned wolf, Chrysocyon brachyurus, in Central Brazil. J Zool 240: 277-284.

Murie OJ 1974. Animals Track. Peterson Field Guild Series, 2nd ed., Houghton Mifflin, Boston, 375 pp.

Nagy JG, Gilbert 1968. Fecal pH values of mule deer and grazing domestic sheep. J Wildl Mgmt 32: 961-962.

Neff DJ 1968. The pellet-group count technique for big game trend, census, and distribution: a review. J Wildl Mgmt 32: 597-614.

Page LK, Swihart RK, Kazacos KR 2001. Seed preferences and foranging by granivores at raccoon latrines in the transmission dynamics of raccoon roundworm (Baylisascaris procyonis). Can J Zool 79: 616-622.

Patterson BR, Benjamin LK, Messier F. 1998. Prey switching and feeding habits of eastern coyotes in relation to snowshoe hare and white-tailed deer densities. Can J Zool 76: 1885-1897.

Patton S, Rabinowitz A, Randolph S, Johnson SS 1986. A coprological survey of parasites of Neotropical Felidae. $J$ Parasitol 72: 517-520.

Pizo MA, Oliveira PS 1999. Removal seeds from vertebrate faeces by ants: effects os seed species and deposition site. Can J Zool 77: 1595-1602.

Putman RJ 1984. Facts from faeces. Mammal Revue 14: 79-97.

Reed J, Tollit DJ, Thompson PM, Amos W 1997. Molecular scatology: the use of molecular genetic analysis to assign species, sex and individual identity to seal faeces. Mol Ecol 6: $225-234$

Rollins D, Bryan FC, Montadon 1984. Fecal pH and defecation rates of eight ruminants fed known diets. $J$ Wildl Mgmt 48: $807-813$
Romo MC 1995. Food habits of the Andean fox (Pseudalopex culpaeus) and notes on the mountain cat (Puma colocolo) and puma (Felis concolor) in the Rio Abiseo National Park, Peru. Mammalia 59: 335-343.

Russo R, Olhausen P 1987. Pacific Coast Mammals, Nature Study Guild, California, 93 pp.

Santos MFM, Hartz SM 1999. The food habits of Procyon cancrivorus (Carnivora, Procyonidae) in the Lami Biological Reserve, Porto Alegre, Southern Brazil. Mammalia 63: 525-530.

Seton ET 1925. On the study of scatology. J Mamm 6: 47-49.

Stokes D, Stokes L 1986. Animals Tracking and Behaviour, Stokes Nature Guides, Little Brown, Cape Town, 418 pp.

Stuart C, Stuart T 1996. Field guide to the Larger Mammals of Africa, Struik Publishers, Cape Town, 318 pp.

Stuart C, Stuart T 1998. A Field Guide to the Tracks and Signs of Southern and East African Wildlife, Southern Books Publishers, Cape Town, 310 pp.

Walker C 1996. Signs of the Wild, Struik Publish, Cape Town, $215 \mathrm{pp}$.

Weaver JL, Fritts SH 1979. Comparison of coyote and wolf scat diameters. $J$ Wildl Mgmt 43: 786-788.

Weaver JL, Hoffman SW 1979. Differential detectability of rodentes in coyote scats. $J$ Wildl Mgmt 43: 783-786.

Wemmer C, Kunz TH, Lundie-Jenkins G, McShea W. 1996. Mammalian sign. In DE Wilson, FR Cole, JD Nichols, R Rudran, MS Foster (eds), Measuring and Monitoring Biological Diversity - Standard Methods for Mammals, Smithsonian Institution Press, Washington, p. 157-176.

Williams PA, Karl BJ, Bannister P, Lee WG 2000. Small mammals as potencial seed disperses in New Zeland. Austral Ecol 25: 523-532.

TABLE I

Feces' measures and shapes from African mammals

\begin{tabular}{|c|c|c|c|}
\hline Mammals' species & $\begin{array}{c}\text { Feces' measures } \\
\mathrm{L} \text { x W cm } \\
\varnothing \mathrm{cm}\end{array}$ & Feces' shape & References \\
\hline
\end{tabular}

\section{LAGOMORPHA}

\begin{tabular}{lll}
\hline Leporidae & $\mathrm{L}=1 \mathrm{~cm}$ & $\begin{array}{l}\text { Lienbenberg } 2000 \\
\text { Walker } 1996\end{array}$ \\
\hline $\begin{array}{l}\text { Lepus saxatilis } \\
\text { (Hare) }\end{array}$ & $\mathrm{L}=1 \mathrm{~cm}$ & Walker 1996 \\
\hline $\begin{array}{l}\text { Lepus capensis } \\
\text { (Cape Hare) }\end{array}$ &
\end{tabular}

\section{RODENTIA}

Sciuridae

Xerus inaurus

(Ground squirel)
$1.5 \times 0.5 \mathrm{~cm}$

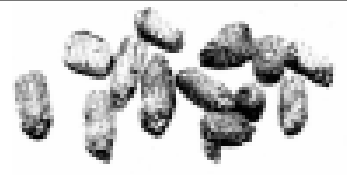

Walker 1996 


\begin{tabular}{|c|c|c|}
\hline Mammals' species & $\begin{array}{l}\text { Feces' measures } \\
\text { Lx W cm }\end{array}$ & References \\
\hline $\begin{array}{l}\text { Paraxerus cepapi } \\
\text { (Tree Squirel) }\end{array}$ & $\mathrm{L}=0.5 \mathrm{~cm}$ & Walker 1996 \\
\hline $\begin{array}{l}\text { Pedestes capensis } \\
\text { (Springhare) }\end{array}$ & $\mathrm{L}=2 \mathrm{~cm}$ & $\begin{array}{l}\text { Lienbenberg } 2000 \\
\text { Walker } 1996\end{array}$ \\
\hline \multicolumn{3}{|l|}{ Thryonomyidae } \\
\hline $\begin{array}{l}\text { Thryonomys swinderianus } \\
\text { (Greater Cane-rat) }\end{array}$ & $\mathrm{L}=2 \mathrm{~cm}$ & $\begin{array}{l}\text { Walker } 1996 \\
\text { Stuert \& Stuart } 1998\end{array}$ \\
\hline \multicolumn{3}{|l|}{ Hystricidae } \\
\hline $\begin{array}{l}\text { Histrix africaeaustralis } \\
\text { (Porcupine) }\end{array}$ & $5 \mathrm{~cm}$ & $\begin{array}{l}\text { Lienbenberg } 2000 \\
\text { Walker } 1996\end{array}$ \\
\hline
\end{tabular}

\section{INSETIVORA}

Erinaceidae

Atelirix frontalis

(Hedgehog)

$$
\mathrm{L}=1.5 \mathrm{~cm}
$$

Walker 1996

\section{PRIMATA}

STREPSIRHINI (Prosimians)

Galogonidae

Galago moholi

(Lesser Bushbaby)

$\mathrm{L}=5 \mathrm{~cm} \quad$ amorph $\quad$ Walker 1996

CATARRHINI (Old monkeys and man)

Cercopithecidae

\begin{tabular}{|c|c|c|}
\hline $\begin{array}{l}\text { Papio cynocephalus } \\
\text { P.urcinus } \\
\text { (Chacma baboon) }\end{array}$ & $\mathrm{L}=5-10 \mathrm{~cm}$ & $\begin{array}{l}\text { Lienbenberg } 2000 \\
\text { Walker } 1996\end{array}$ \\
\hline $\begin{array}{l}\text { Cercopithecus aethiop } \\
\text { Cercopithecus mitis (n }\end{array}$ & $\mathrm{L}=3-5 \mathrm{~cm}$ & $\begin{array}{l}\text { Lienbenberg } 2000 \\
\text { Walker } 1996\end{array}$ \\
\hline
\end{tabular}

CARNIVORA

Canidae

Lycaon pictus

(Wild dog)

$7.5 \times 2.9 \mathrm{~cm}$

Vulpes chama

(Cape Fox)

Otocyon megalotis

(Bat-eared Fox)

$9.5 \times 1.8 \mathrm{~cm}$

$3.4 \times 2 \mathrm{~cm}$
Canis mesonelas

(Black-backed Jackal)
$7.4 \times 2 \mathrm{~cm}$
Walker 1996

Walker 1996

Walker 1996

Walker 1996 


\begin{tabular}{|c|c|c|c|}
\hline Mammals' species & $\begin{array}{c}\text { Feces' measures } \\
\text { L x W cm } \\
\varnothing \mathrm{cm}\end{array}$ & Feces' shape & References \\
\hline $\begin{array}{l}\text { Canis adustrus } \\
\text { (Side-Stripped Jackal) }\end{array}$ & $9.6 \times 1.5 \mathrm{~cm}$ & & Walker 1996 \\
\hline \multicolumn{4}{|l|}{ Mustelidae } \\
\hline $\begin{array}{l}\text { Ictonys striatus } \\
\text { (Striped Polecat) }\end{array}$ & $6.8 \times 5.4 \mathrm{~cm}$ & & Walker 1996 \\
\hline $\begin{array}{l}\text { Mellivora capensis } \\
\text { (Honey Badger) }\end{array}$ & $6.8 \times 2.2 \mathrm{~cm}$ & & Walker 1996 \\
\hline
\end{tabular}

\begin{tabular}{lcc}
\hline Lutrinae & $\mathrm{L}=8 \mathrm{~cm}$ & Lienbernberg 2000 \\
\hline $\begin{array}{l}\text { Aonyx capensis } \\
\text { (Cape Clawless otter) }\end{array}$ & $5 \times 2.6 \mathrm{~cm}$ & Walker 1996 \\
\hline $\begin{array}{l}\text { Lutra maculicolis } \\
\text { (Spotted-necked Otter) }\end{array}$ & $3.4 \times 2.6 \mathrm{~cm}$ & Walker 1996
\end{tabular}

Hyaenidae

Hyaena brunnea

(Brown Hyaena)

Crocuta crocuta

(Spotted Hyaena)

Proteles cristata

Proteles crista
(Aardwolf)
$\mathrm{L}=5 \mathrm{~cm}$

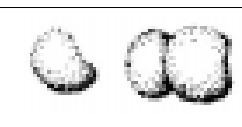

Lienbernberg 2000

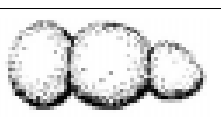

Walker 1996

$11.2 \times 4.5 \mathrm{~cm}$

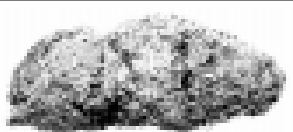

Viverridae

\begin{tabular}{lll}
\hline $\begin{array}{l}\text { Genetta tigrina } \\
\text { (Large-spotted Genet) }\end{array}$ & $7.5 \times 1.5 \mathrm{~cm}$ & Walker 1996 \\
\hline $\begin{array}{l}\text { Genetta genetta } \\
\text { (small-spotted Genet) }\end{array}$ & $5.5 \times 4.7 \mathrm{~cm}$ & Walker 1996 \\
\hline
\end{tabular}

Herpestidae

Suricata suricatta

$5 \times 1.8 \mathrm{~cm}$

(Suricate)

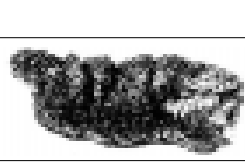

Rhynchogale melleri

(Meller's Mongoose)

$8 \times 1 \mathrm{~cm}$

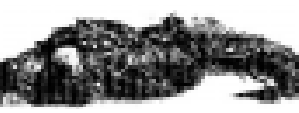

Walker 1996

Walker 1996

Cynictis penicillata

(Yellow Mongoose)

$4.4 \times 1 \mathrm{~cm}$

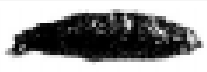

Walker 1996

Galerella pulverulenta

(Small Grey Mongoose)

$4 \times 2 \mathrm{~cm}$

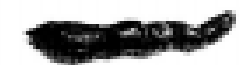

Walker 1996

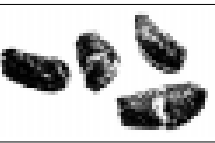




\begin{tabular}{|c|c|c|c|}
\hline Mammals' species & $\begin{array}{c}\text { Feces' measures } \\
\mathrm{L} \text { x W cm } \\
\varnothing \mathrm{cm}\end{array}$ & Feces' shape & References \\
\hline $\begin{array}{l}\text { Ichneumia albicauda } \\
\text { (White-tailed Mongoose) }\end{array}$ & $7 \times 1.3 \mathrm{~cm}$ & & Walker 1996 \\
\hline $\begin{array}{l}\text { Atilax paludinosus } \\
\text { (Water Mongoose) }\end{array}$ & $3.2 \times 2.2 \mathrm{~cm}$ & & Walker 1996 \\
\hline $\begin{array}{l}\text { Herpestes ichneumon } \\
\text { (Large Grey Mongoose) }\end{array}$ & $9 \times 2.3 \mathrm{~m}$ & & Walker 1996 \\
\hline $\begin{array}{l}\text { Galerella sanguinea } \\
\text { (Slender Mongoose) }\end{array}$ & $7 \times 1.3 \mathrm{~cm}$ & & Walker 1996 \\
\hline $\begin{array}{l}\text { Mungus mungo } \\
\text { (Banded Mongoose) }\end{array}$ & $3.2 \times 1.2 \mathrm{~cm}$ & & Walker 1996 \\
\hline $\begin{array}{l}\text { Helogale parvula } \\
\text { (Dwarf Mongoose) }\end{array}$ & $3.6 \times 1.5 \mathrm{~cm}$ & & Walker 1996 \\
\hline \multicolumn{4}{|l|}{ Felidae } \\
\hline $\begin{array}{l}\text { Panthera leo } \\
\text { (Lion) }\end{array}$ & $15 \times 4.4 \mathrm{~cm}$ & & $\begin{array}{l}\text { Walker } 1996 \\
\text { Stuart \& Stuart } 1998\end{array}$ \\
\hline $\begin{array}{l}\text { Panthera pardus } \\
\text { (Leopard) }\end{array}$ & No data & & Walker 1996 \\
\hline $\begin{array}{l}\text { Felis caracal } \\
\text { (Caracal) }\end{array}$ & $5.5 \times 1.7 \mathrm{~cm}$ & & Walker 1996 \\
\hline $\begin{array}{l}\text { Felis serval } \\
\text { (Serval) }\end{array}$ & $12 \times 2.2 \mathrm{~cm}$ & & Walker 1996 \\
\hline $\begin{array}{l}\text { Felis lybica } \\
\text { (African Wild cat) }\end{array}$ & $3.5 \times 2 \mathrm{~cm}$ & & Walker 1996 \\
\hline $\begin{array}{l}\text { Felis nigripes } \\
\text { (Small spotted cat) }\end{array}$ & $\begin{array}{l}4.7 \times 1.8 \mathrm{~cm} \\
1-1.4 \mathrm{~cm} \varnothing\end{array}$ & & $\begin{array}{l}\text { Walker } 1996 \\
\text { Stuart \& Stuart } 1998\end{array}$ \\
\hline $\begin{array}{l}\text { Dendrohyrax arboreus } \\
\text { (Tree Dassie) }\end{array}$ & $6.6 \times 2.4 \mathrm{~cm}$ & & Walker 1996 \\
\hline
\end{tabular}




\begin{tabular}{ccc}
\hline & Feces' measures & \\
L $\mathrm{x} \mathrm{W} \mathrm{cm}$ & Feces' shape & References \\
$\varnothing \mathrm{cm}$ & &
\end{tabular}

UNGULATA (Super Order)

TUBILIDENTATA

Orycteropodidae

Orycteropus afer

(Antbear)

$\mathrm{L}=4 \mathrm{~cm}$

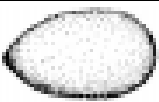

Lienbenberg 2000

\section{HYRACOIDEA}

Procavidae

Procavia capensis

(Dassie or Rocky Hyrax)

$\mathrm{L}=1 \mathrm{~cm}$

$1.5 \times 1 \mathrm{~cm}$

Lienbenberg 2000

Heterohyrax brucei

$1.5 \times 1 \mathrm{~cm}$

Walker 1996

(Yellow-spotted Rock Dassie)

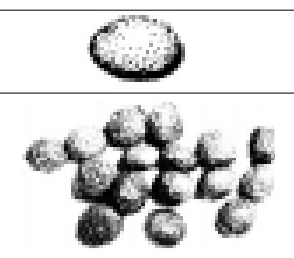

Walker 1996

\section{PROBOSCIDAE}

Elephantidae

Loxodonta africana

(Elephant)

$\mathrm{L}=15-20 \mathrm{~cm}$

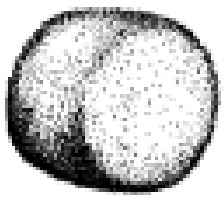

Lienbenberg 2000

PERISSODATYLA

\section{Equidae}

Equus burchelli

$6 \times 4 \mathrm{~cm}$

Walker 1996

(Burchell's Zebra)

$\mathrm{L}=5 \mathrm{~cm}$

Equus zebra zebra

(Mountain Zebra)

Rhinocerotidae

Ceratotherium simum

(White Rhino)

$\mathrm{L}=10-15 \mathrm{~cm}$

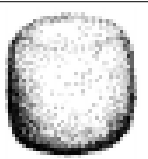

Lienbenberg 2000

Diceros bicornis

(Black Rhino)

\section{ARTIODACTYLA}

Hippopotamidae

$\begin{array}{ll}\text { Hippopotamus amphibius } & \mathrm{L}=10 \mathrm{~cm} \\ \text { (Hippo) } & \end{array}$
(Hippo)

\section{Suidae}

Potamochoerus porcus (Bushpig) 


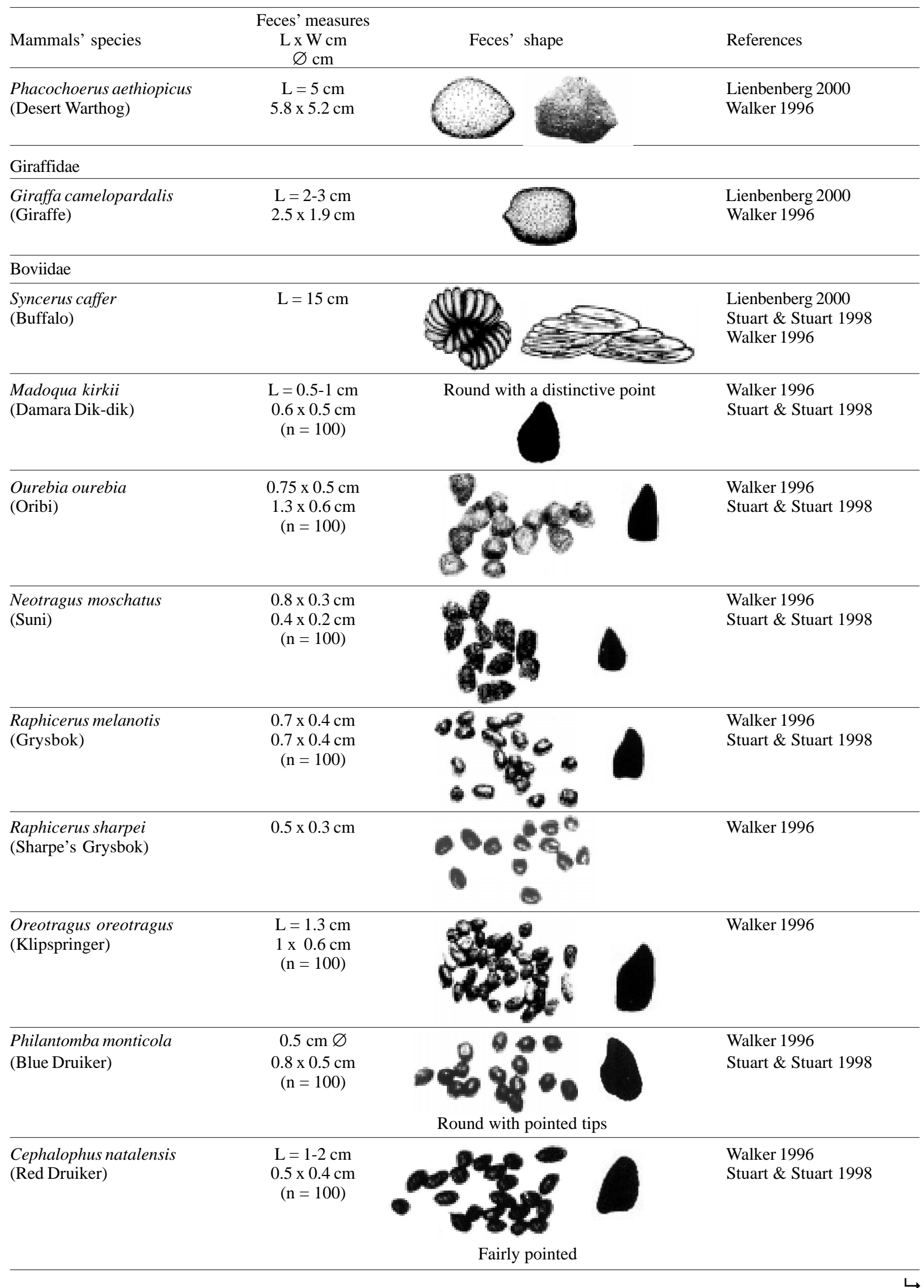




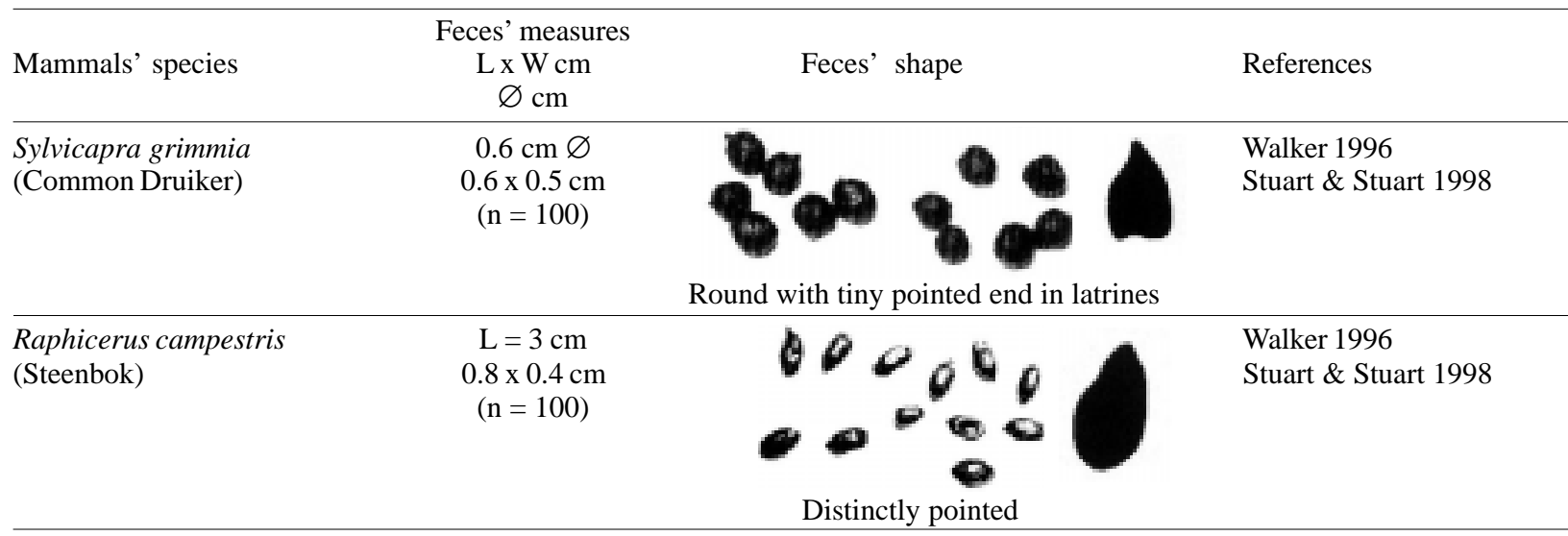

Damaliscus dorcas phillipsi (Blesbok)

\section{$1.3 \times 1.1 \mathrm{~cm}$}

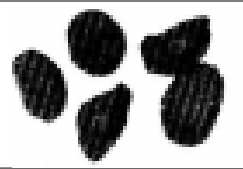

Damaliscus dorcas dorcas (Bontebok)

\begin{tabular}{lc} 
& $\begin{array}{c}1.5 \times 0.9 \mathrm{~cm} \\
(\mathrm{n}=100)\end{array}$ \\
& \\
\hline Damaliscus lunatus & $2.2 \times 1.8 \mathrm{~cm}$ \\
(Topi, Tiang or Tsessebe) & $2.1 \times 1.3 \mathrm{~cm}$ \\
& $(\mathrm{n}=100)$
\end{tabular}

$1.3 \times 1.1 \mathrm{~cm}$ $1.5 \times 0.9 \mathrm{~cm}$ $(\mathrm{n}=100)$
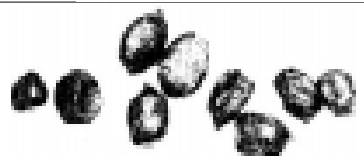

Walker 1996

Walker 1996

Stuart \& Stuart 1998

Walker 1996

Stuart \& Stuart 1998

More pointed than that of the others species of the genus

\begin{tabular}{lc}
\hline Redunca arundinum & $1.7 \times 1 \mathrm{~cm}$ \\
(Reedbuck) & $1.2 \times 0.9 \mathrm{~cm}$ \\
& $(\mathrm{n}=100)$
\end{tabular}
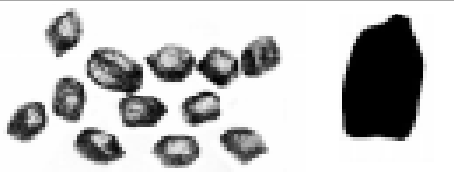

Walker 1996

Stuart \& Stuart 1998

\begin{tabular}{lc}
\hline Redunca fulvorufula & $1 \mathrm{~cm} \varnothing$ \\
(Mountain Reedbuck) & $0.9 \times 0.4 \mathrm{~cm}$ \\
& $(\mathrm{n}=100)$
\end{tabular}

Antidorcas marsupialis

(Springbok)

$1.3 \mathrm{~cm} \varnothing$
$1.1 \times 0.7 \mathrm{~cm}$
$(\mathrm{n}=100)$

Clusters and single pellets
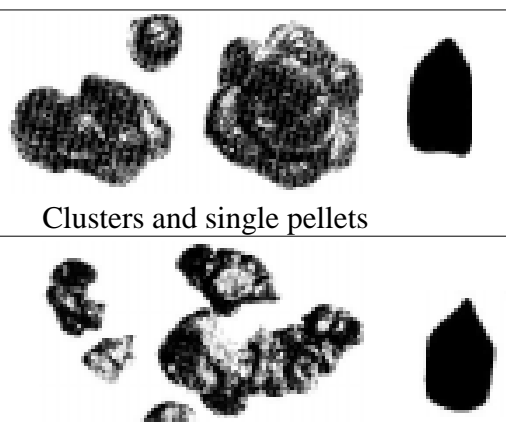

Walker 1996

Stuart \& Stuart 1998

Clusters and single pellets

\begin{tabular}{lc}
\hline $\begin{array}{l}\text { Aepyceros melampus } \\
\text { (Impala) }\end{array}$ & $\begin{array}{c}1-2 \times 0.7 \mathrm{~cm} \\
1.1 \times 0.6 \mathrm{~cm} \\
(\mathrm{n}=100)\end{array}$ \\
\hline $\begin{array}{lc}\text { Connochaetes taurinus } \\
\text { (Blue Wildbeest) }\end{array}$ & $\begin{array}{c}2 \times 1 \mathrm{~cm} \\
(\mathrm{n}=100)\end{array}$
\end{tabular}

Connochaetes gnou

(Black Wildebeest)
No data

(similar G. taurinus)

$1.5 \times 1 \mathrm{~cm}$

$(\mathrm{n}=100)$
Walker 1996

Stuart \& Stuart 1998 


\begin{tabular}{|c|c|c|c|}
\hline Mammals' species & $\begin{array}{c}\text { Feces' measures } \\
\mathrm{Lx} \mathrm{W} \mathrm{cm} \\
\varnothing \mathrm{cm}\end{array}$ & Feces' shape & References \\
\hline $\begin{array}{l}\text { Gazella rufifrons } \\
\text { (Thomson's Gazelle) }\end{array}$ & $\begin{array}{l}1 \times 0.6 \mathrm{~cm} \\
(\mathrm{n}=100)\end{array}$ & & Stuart \& Stuart 1998 \\
\hline $\begin{array}{l}\text { Gazella granti } \\
\text { (Grant's Gazelle) }\end{array}$ & $\begin{array}{l}1 \times 0.6 \mathrm{~cm} \\
(\mathrm{n}=100)\end{array}$ & & Stuart \& Stuart 1998 \\
\hline $\begin{array}{l}\text { Oryx gazella } \\
\text { (Gemsbok) }\end{array}$ & $\begin{array}{c}\mathrm{L}>1.7 \mathrm{~cm} \\
1.6 \times 1.1 \mathrm{~cm} \\
(\mathrm{n}=100)\end{array}$ & & $\begin{array}{l}\text { Walker } 1996 \\
\text { Stuart \& Stuart } 1998\end{array}$ \\
\hline $\begin{array}{l}\text { Alcelaphus buselaphus } \\
\text { (Red Hartebeest) }\end{array}$ & $\begin{array}{c}0.8 \times 0.7 \mathrm{~cm} \\
1.7 \times 1 \mathrm{~cm} \\
(\mathrm{n}=100)\end{array}$ & & $\begin{array}{l}\text { Walker } 1996 \\
\text { Stuart \& Stuart } 1998\end{array}$ \\
\hline $\begin{array}{l}\text { Hippotragus niger } \\
\text { (Sable) }\end{array}$ & $\begin{array}{l}\mathrm{L}=1.5 \mathrm{~cm} \\
2 \times 1.3 \mathrm{~cm} \\
(\mathrm{n}=100)\end{array}$ & & $\begin{array}{l}\text { Walker } 1996 \\
\text { Stuart \& Stuart } 1998\end{array}$ \\
\hline $\begin{array}{l}\text { Hippotragus aquinus } \\
\text { (Roan Antelope) }\end{array}$ & $\begin{array}{l}\mathrm{L}=2.7 \mathrm{~cm} \\
2 \times 1.2 \mathrm{~cm} \\
(\mathrm{n}=100)\end{array}$ & & $\begin{array}{l}\text { Walker } 1996 \\
\text { Stuart \& Stuart } 1998\end{array}$ \\
\hline $\begin{array}{l}\text { Kobus vardonii } \\
\text { (Puku) }\end{array}$ & $1.1 \mathrm{~cm} \varnothing$ & & Walker 1996 \\
\hline $\begin{array}{l}\text { Kobus leche } \\
\text { (Red Lechwe) }\end{array}$ & $\begin{array}{c}1.6 \mathrm{~cm} \varnothing \\
1.4 \times 1.4 \mathrm{~cm} \\
(\mathrm{n}=100)\end{array}$ & & $\begin{array}{l}\text { Walker } 1996 \\
\text { Stuart \& Stuart } 1998\end{array}$ \\
\hline $\begin{array}{l}\text { Kobus ellipsiprymnus } \\
\text { (Waterbuck) }\end{array}$ & $\begin{array}{l}\text { No data } \\
2 \times 1.4 \mathrm{~cm} \\
(\mathrm{n}=100)\end{array}$ & Clusters & $\begin{array}{l}\text { Walker } 1996 \\
\text { Stuart \& Stuart } 1998\end{array}$ \\
\hline $\begin{array}{l}\text { Tragelaphus scriptus } \\
\text { (Bushbuck) }\end{array}$ & $\begin{array}{c}\text { Cakes } \\
3.3-2.2 \mathrm{~cm} \\
1.4 \times 0.6 \mathrm{~cm} \\
(\mathrm{n}=100)\end{array}$ & Clusters & $\begin{array}{l}\text { Walker } 1996 \\
\text { Stuart \& Stuart } 1998\end{array}$ \\
\hline $\begin{array}{l}\text { Tragelaphus angasii } \\
\text { (Nyala) }\end{array}$ & $\begin{array}{l}\mathrm{L}=1.5 \mathrm{~cm} \\
1.6 \times 1 \mathrm{~cm} \\
(\mathrm{n}=100)\end{array}$ & & $\begin{array}{l}\text { Walker } 1996 \\
\text { Stuart \& Stuart } 1998\end{array}$ \\
\hline $\begin{array}{l}\text { Tragelaphus spekei } \\
\text { (Sitatunga) }\end{array}$ & $2.5 \times 1.3 \mathrm{~cm}$ & & Walker 1996 \\
\hline
\end{tabular}




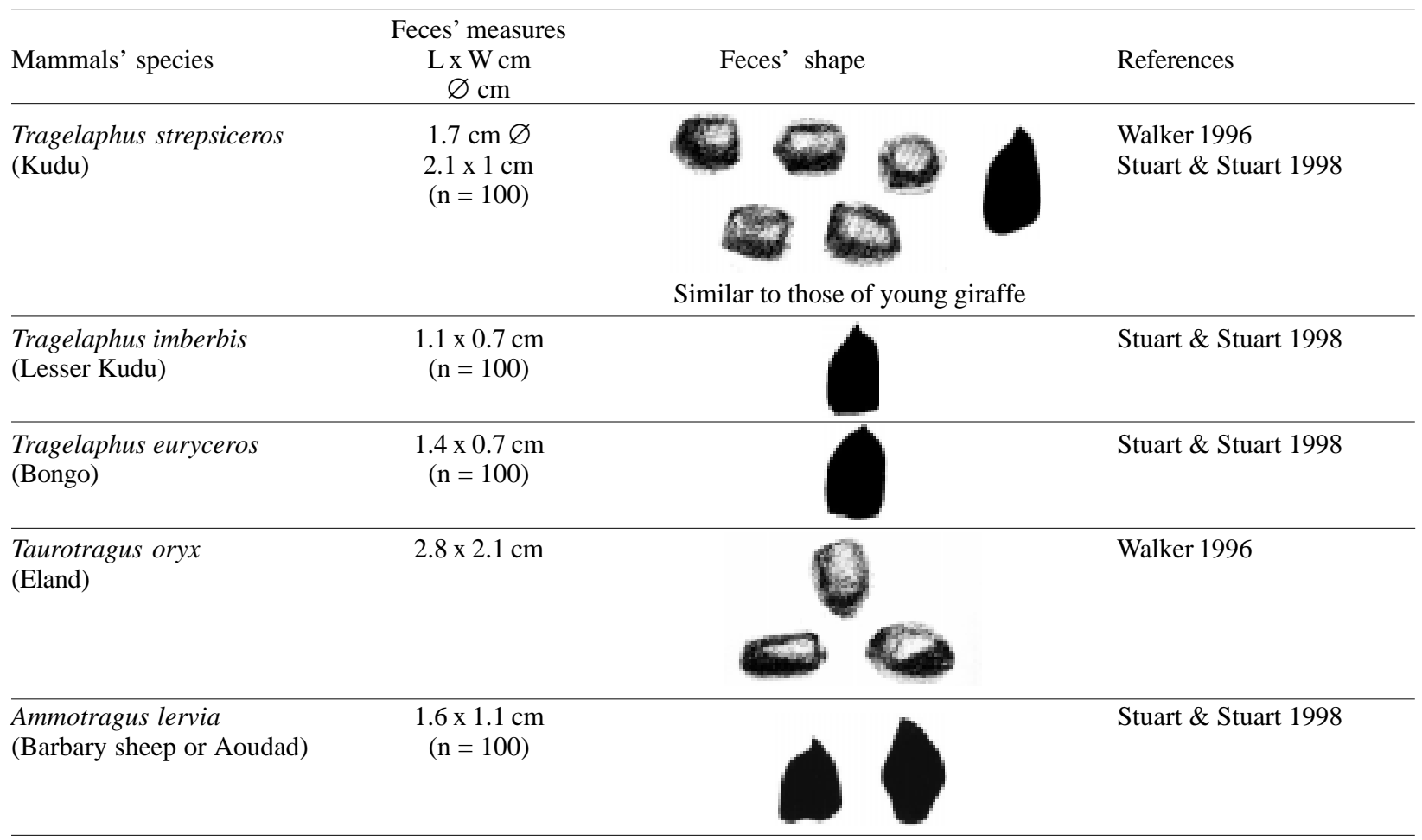

TABLE II

Feces' measures and shapes from North American mammals

\begin{tabular}{|c|c|c|c|}
\hline \multirow{2}{*}{ Mammals' species } & Feces' measure & \multirow[b]{2}{*}{ Feces' shape } & \\
\hline & $\begin{array}{c}\mathrm{Lx} \mathrm{W} \mathrm{cm} \\
\varnothing \mathrm{cm}\end{array}$ & & References \\
\hline
\end{tabular}

MARSUPIALIA

Didelphidae

Didelphis marsupialis $\quad \mathrm{L}=4.2 \mathrm{~cm}$

(Opossum)

$\mathrm{L}=4.4 \mathrm{~cm}$

Russo \& Olhausen 1987

Murie 1982

Stokes \& Stokes 1986

\section{XENARTHRA}

Dasypodidae

Dasypus novemcinctus

$\mathrm{L}=3.5 \mathrm{~cm}$

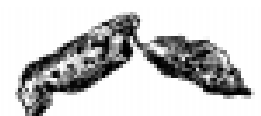

29:5

Murie 1982

\section{INSETIVORA}

\begin{tabular}{ll}
\hline $\begin{array}{l}\text { Soricidae } \\
\text { (Artic Shrew) }\end{array}$ & $0.4 \times 0.1 \mathrm{~cm}$ \\
\hline $\begin{array}{l}\text { Blarina brevicauda } \\
\text { (shorttail Shrew) }\end{array}$ & $1.2 \times 0.2 \mathrm{~cm}$ \\
\hline $\begin{array}{l}\text { Cryptotis parva } \\
\text { (Pygmy Shrew) }\end{array}$ & $0.6 \times 0.1 \mathrm{~cm}$
\end{tabular}




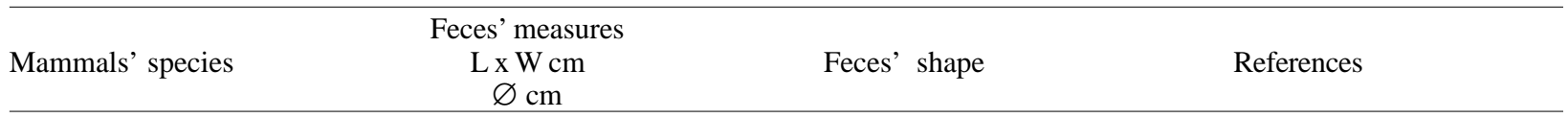

\section{LAGOMORPHA}

Leporidae

Lepus californicus

$\mathrm{L}=1-1.2 \mathrm{~cm}$

(Blacktail Jackrabbit or

Blacktail Hare)

$\mathrm{x} \mathrm{W} \mathrm{cm}$

Russo \& Olhausen 1987

Lepus townsendii

(Whitetail Jackrabbit or

Whitetail Hare)

\begin{tabular}{ll}
\hline Lepus americanus & $\mathrm{L}=1-1.3 \mathrm{~cm}$
\end{tabular}

(Snowshoe Hare)

$\mathrm{L}=1.8 \mathrm{~cm}$

$1.3-1.7 \times 1.4-0.9 \mathrm{~cm}$

60

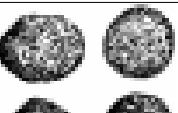

8. 62

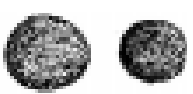

Russo \& Olhausen 1987

Murie 1982

Russo \& Olhausen 1987

Murie 1982

Murie 1982

Lepus arcticus $\quad 1.6 \times 1.4 \mathrm{~cm}$

(Artic Hare or Tundra Hare)

Give 80

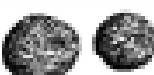

A3.

$1.7 \times 1.1 \mathrm{~cm}$

Lepus europaeus

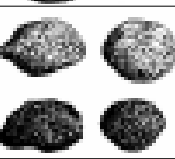

Murie 1982

(European Hare)

$\mathrm{L}=0.6-0.8 \mathrm{~cm}$

Sylvilagus bachmani

(Brush Rabbit)

Sylvilagus nuttallii

$\mathrm{L}=0.7-0.9 \mathrm{~cm}$

(Mountain Cottontail)

$\mathrm{L}=0.8 \mathrm{~cm}$

Sylvilagus audubonii

(Audubon Cottontail or

Desert Cottontail)

Sylvilagus floridanus

(Cottontail)

$0.7-0.9 \mathrm{~cm} \varnothing$
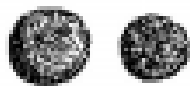

Murie 1982

Stokes \& Stokes 1986

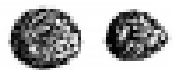

Sylvilagus idahoensis

(Pygmy Rabbit)

$0.3-0.6 \mathrm{~cm} \varnothing$

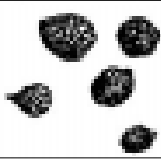

Murie 1982

Ochotonidae

Ochotona princeps

$\mathrm{L}=3-5 \mathrm{~cm}$

$0.2 \mathrm{~cm} \varnothing$

웅 0

Russo \& Olhausen 1987

(Pika, Cony, Rocky Rabbit

or Piping Hare)

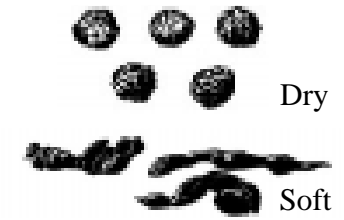

Murie 1982

RODENTIA

Sciuridae

Marmota flaviventris

(Yellow-belled Marmot)

$\mathrm{L}=2.8-4 \mathrm{~cm}$

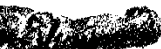

Russo \& Olhausen 1987 


\begin{tabular}{|c|c|c|}
\hline Mammals' species & $\begin{array}{l}\text { Feces' measures } \\
\mathrm{Lx} \mathrm{W} \mathrm{cm} \\
\varnothing \mathrm{cm}\end{array}$ & References \\
\hline $\begin{array}{l}\text { Cynomys spp. } \\
\text { (Prairie Dog) }\end{array}$ & $\mathrm{L}=1-0.5 \mathrm{~cm}$ & Murie 1982 \\
\hline $\begin{array}{l}\text { Citellus variegatus } \\
\text { (larger Rock Squirrel) }\end{array}$ & $1.5 \times 0.7 \mathrm{~cm}$ & Murie 1982 \\
\hline $\begin{array}{l}\text { Citellus armatus } \\
\text { (Uinta Ground Squirrel) }\end{array}$ & $1.3 \times 0.2 \mathrm{~cm}$ & Murie 1982 \\
\hline Tamias striatus lysteri & $0.6 \times 0.2 \mathrm{~cm}$ & Murie 1982 \\
\hline $\begin{array}{l}\text { Eutamias minimus } \\
\text { (Least Chipmunk) }\end{array}$ & $\mathrm{L}=0.5-0.7 \mathrm{~cm}$ & Russo \& Olhausen 1987 \\
\hline $\begin{array}{l}\text { Eutamias speciosus } \\
\text { (Lodgepole Chipmunk) }\end{array}$ & $\mathrm{L}=0.7 \mathrm{~cm}$ & \\
\hline $\begin{array}{l}\text { Eutamias merriami } \\
\text { (Merriam Chipmunk) }\end{array}$ & $\mathrm{L}=0.5-1.2 \mathrm{~cm}$ & Russo \& Olhausen 1987 \\
\hline \multicolumn{3}{|l|}{$\begin{array}{l}\text { Eutamias amoneus } \\
\text { (Yellow pine Chipmunk) }\end{array}$} \\
\hline \multicolumn{3}{|l|}{$\begin{array}{l}\text { Eutamias townsendii } \\
\text { (Townsend Chipmunk) }\end{array}$} \\
\hline \multicolumn{3}{|l|}{$\begin{array}{l}\text { Eutamias sonomae } \\
\text { (Sonoma Chipmunk) }\end{array}$} \\
\hline Eutamias alpinus luteiventris & $1 \times 0.2 \mathrm{~cm}$ & Murie 1982 \\
\hline Eutamias dorsalis & $0.5 \times 0.1 \mathrm{~cm}$ & Murie 1982 \\
\hline $\begin{array}{l}\text { Sciurus carolinensis } \\
\text { (Eastern Gray Squirrel) }\end{array}$ & $1 \times 0.4 \mathrm{~cm}$ & Murie 1982 \\
\hline $\begin{array}{l}\text { Sciurus alberti } \\
\text { (Tassel-eared Squirrel) }\end{array}$ & $0.6 \times 0.3 \mathrm{~cm}$ & Murie 1982 \\
\hline $\begin{array}{l}\text { Sciurus niger } \\
\text { (Fox Squirrel) }\end{array}$ & $\mathrm{L}=1-1.2 \mathrm{~cm}$ & Russo \& Olhausen 1987 \\
\hline $\begin{array}{l}\text { Sciurus griseus } \\
\text { (Western Gray Squirrel) }\end{array}$ & $\mathrm{L}=0.9-1.4 \mathrm{~cm}$ & $\begin{array}{l}\text { Russo \& Olhausen } 1987 \\
\text { Murie } 1982 \\
\text { Stokes \& Stokes } 1986\end{array}$ \\
\hline $\begin{array}{l}\text { Tamiasciurus douglasi } \\
\text { (Chickaree, Douglas Squireel } \\
\text { or Pine Squirrel) }\end{array}$ & $\mathrm{L}=0.6-1 \mathrm{~cm}$ & $\begin{array}{l}\text { Russo \& Olhausen } 1987 \\
\text { Murie } 1982\end{array}$ \\
\hline $\begin{array}{l}\text { Tamiasciurus hudsonicus } \\
\text { (Red Squirrel) }\end{array}$ & $1.5 \times 0.2 \mathrm{~cm}$ & $\begin{array}{l}\text { Murie } 1982 \\
\text { Stokes \& Stokes } 1986\end{array}$ \\
\hline $\begin{array}{l}\text { Glaucomys } \\
\text { (Flying Squirrel) }\end{array}$ & $1.1 \times 0.2 \mathrm{~cm}$ & Murie 1982 \\
\hline $\begin{array}{l}\text { Glaucomys sabrinus } \\
\text { (Northern Flying Squirrel) }\end{array}$ & $\mathrm{L}=0.4-1.2 \mathrm{~cm}$ & \\
\hline $\begin{array}{l}\text { Spermophilus beecheyi } \\
\text { (California Ground Squirrel) }\end{array}$ & $\mathrm{L}=1-1.4 \mathrm{~cm}$ & Russo \& Olhausen 1987 \\
\hline $\begin{array}{l}\text { Spermophilus lateralis } \\
\text { (Golden-mantled Ground Squirrel) }\end{array}$ & $\mathrm{L}=1.2-1.4 \mathrm{~cm}$ & \\
\hline \multicolumn{3}{|l|}{ Geomyidae } \\
\hline $\begin{array}{l}\text { Thomomys talpoides } \\
\text { (Northern Pocket Gophers) }\end{array}$ & $\begin{array}{l}\mathrm{L}=2.8-4 \mathrm{~cm} \\
0.8 \times 0.2 \mathrm{~cm}\end{array}$ & $\begin{array}{l}\text { Russo \& Olhausen } 1987 \\
\text { Murie } 1982\end{array}$ \\
\hline
\end{tabular}




\begin{tabular}{|c|c|c|c|}
\hline Mammals' species & $\begin{array}{c}\text { Feces' measures } \\
\mathrm{Lx} \mathrm{W} \mathrm{cm} \\
\varnothing \mathrm{cm}\end{array}$ & Feces' shape & References \\
\hline $\begin{array}{l}\text { Perognatus parvus } \\
\text { (Pocket mouse) }\end{array}$ & $\begin{array}{l}0.2 \times 0.1-0.05 \mathrm{~cm} \\
0.6 \times 0.2 \mathrm{~cm}\end{array}$ & & Murie 1982 \\
\hline \multicolumn{4}{|l|}{ Castoridae } \\
\hline $\begin{array}{l}\text { Castor canadensis } \\
\text { (Beaver) }\end{array}$ & $\mathrm{L}=1.5 \mathrm{~cm}$ & & $\begin{array}{l}\text { Russo \& Olhausen } 1987 \\
\text { Murie } 1982\end{array}$ \\
\hline \multicolumn{4}{|l|}{ Microtinae } \\
\hline $\begin{array}{l}\text { Ondatra zibethica } \\
\text { (Muskrat) }\end{array}$ & $\mathrm{L}=1.0-1.3 \mathrm{~cm}$ & & $\begin{array}{l}\text { Murie } 1982 \\
\text { Russo \& Olhausen } 1987 \\
\text { Stokes \& Stokes } 1986\end{array}$ \\
\hline $\begin{array}{l}\text { Neofiber hallen } \\
\text { (Florida water rat) }\end{array}$ & $1.4 \times 0.4 \mathrm{~cm}$ & & Murie 1982 \\
\hline \multicolumn{4}{|l|}{ Erithizontidae } \\
\hline $\begin{array}{l}\text { Erithizon dorsatum } \\
\text { (Porcupine) }\end{array}$ & $\mathrm{L}=3.5-4.7 \mathrm{~cm}$ & & $\begin{array}{l}\text { Russo \& Olhausen } 1987 \\
\text { Murie } 1982 \\
\text { Stokes \& Stokes } 1986\end{array}$ \\
\hline \multicolumn{4}{|l|}{ Aplodontiidae } \\
\hline $\begin{array}{l}\text { Aplodontia rufa } \\
\text { (Aplodontia) }\end{array}$ & $1.5 \times 0.5 \mathrm{~cm}$ & & Murie 1982 \\
\hline \multicolumn{4}{|l|}{ Caviidae } \\
\hline $\begin{array}{l}\text { Dasyprocta } \\
\text { (Agouti) }\end{array}$ & $4 \times 1.5 \mathrm{~cm}$ & & Murie 1982 \\
\hline \multicolumn{4}{|l|}{ Dasyproctidae } \\
\hline $\begin{array}{l}\text { Cuniculus paca } \\
\text { (Paca) }\end{array}$ & $3 \times 1.5 \mathrm{~cm}$ & & Murie 1982 \\
\hline \multicolumn{4}{|l|}{ Zapodidae } \\
\hline $\begin{array}{l}\text { Zapus } \\
\text { (Jumping mouse) }\end{array}$ & $0.9 \times 0.1 \mathrm{~cm}$ & & Murie 1982 \\
\hline \multicolumn{4}{|l|}{ Cricetidae } \\
\hline $\begin{array}{l}\text { Neotoma fuscipes } \\
\text { (Dusky-footed Woodrat) }\end{array}$ & $1 \times 1.4 \mathrm{~cm}$ & & Russo \& Olhausen 1987 \\
\hline $\begin{array}{l}\text { Neotoma cinerea } \\
\text { (Bushytail Woodrat) }\end{array}$ & $0.3 \times 0.2 \mathrm{~cm}$ & & $\begin{array}{l}\text { Russo \& Olhausen } 1987 \\
\text { Murie } 1982\end{array}$ \\
\hline $\begin{array}{l}\text { Neotoma lepida } \\
\text { (Desert Woodrat) }\end{array}$ & $\mathrm{L}=1-1.4 \mathrm{~cm}$ & & Russo \& Olhausen 1987 \\
\hline $\begin{array}{l}\text { Peromyscus } \\
\text { (White-Footed Mouse } \\
\text { or Deer Mouse) }\end{array}$ & $1.7 \times 0.3 \mathrm{~cm}$ & & Murie 1982 \\
\hline $\begin{array}{l}\text { Onychomys } \\
\text { (Grasshopper Mouse) }\end{array}$ & $1 \times 0.2 \mathrm{~cm}$ & & Murie 1982 \\
\hline $\begin{array}{l}\text { Reithrodontomys } \\
\text { (Harvest Mouse) }\end{array}$ & $0.4 \times 0.1 \mathrm{~cm}$ & & Murie 1982 \\
\hline $\begin{array}{l}\text { Oryzomys } \\
\text { (Rice Rat) }\end{array}$ & $1.4 \times 0.2 \mathrm{~cm}$ & & Murie 1982 \\
\hline $\begin{array}{l}\text { Sigmodon } \\
\text { (Cotton Rat) }\end{array}$ & $0.8 \times 0.1 \mathrm{~cm}$ & & Murie 1982 \\
\hline
\end{tabular}




\begin{tabular}{|c|c|c|c|}
\hline Mammals' species & $\begin{array}{c}\text { Feces' measures } \\
\text { Lx W cm } \\
\varnothing \mathrm{cm}\end{array}$ & Feces' shape & References \\
\hline \multicolumn{4}{|l|}{ Microtinae } \\
\hline Micritus miuru & $0.6 \times 0.1 \mathrm{~cm}$ & & \\
\hline $\begin{array}{l}\text { Microtus richardsoni } \\
\text { (Richardson Vole) }\end{array}$ & $0.7 \times 0.2 \mathrm{~cm}$ & & Murie 1982 \\
\hline $\begin{array}{l}\text { Microtus montanus } \\
\text { (Mountain Vole) }\end{array}$ & $0.5-0.2 \times 0.1 \mathrm{~cm}$ & & \\
\hline Microtus operarius & $0.3 \times 0.1 \mathrm{~cm}$ & $\infty$ & Murie 1982 \\
\hline $\begin{array}{l}\text { Dicrostonys groelandicus } \\
\text { (Collared lemming) }\end{array}$ & $0.7-0.3 \times 0.2 \mathrm{~cm}$ & & Murie 1982 \\
\hline $\begin{array}{l}\text { Lemmus trimucronatus } \\
\text { (Brown lemming) }\end{array}$ & 0.4 x $0.2-0.1 \mathrm{~cm}$ & & Murie 1982 \\
\hline
\end{tabular}

\section{CARNIVORA}

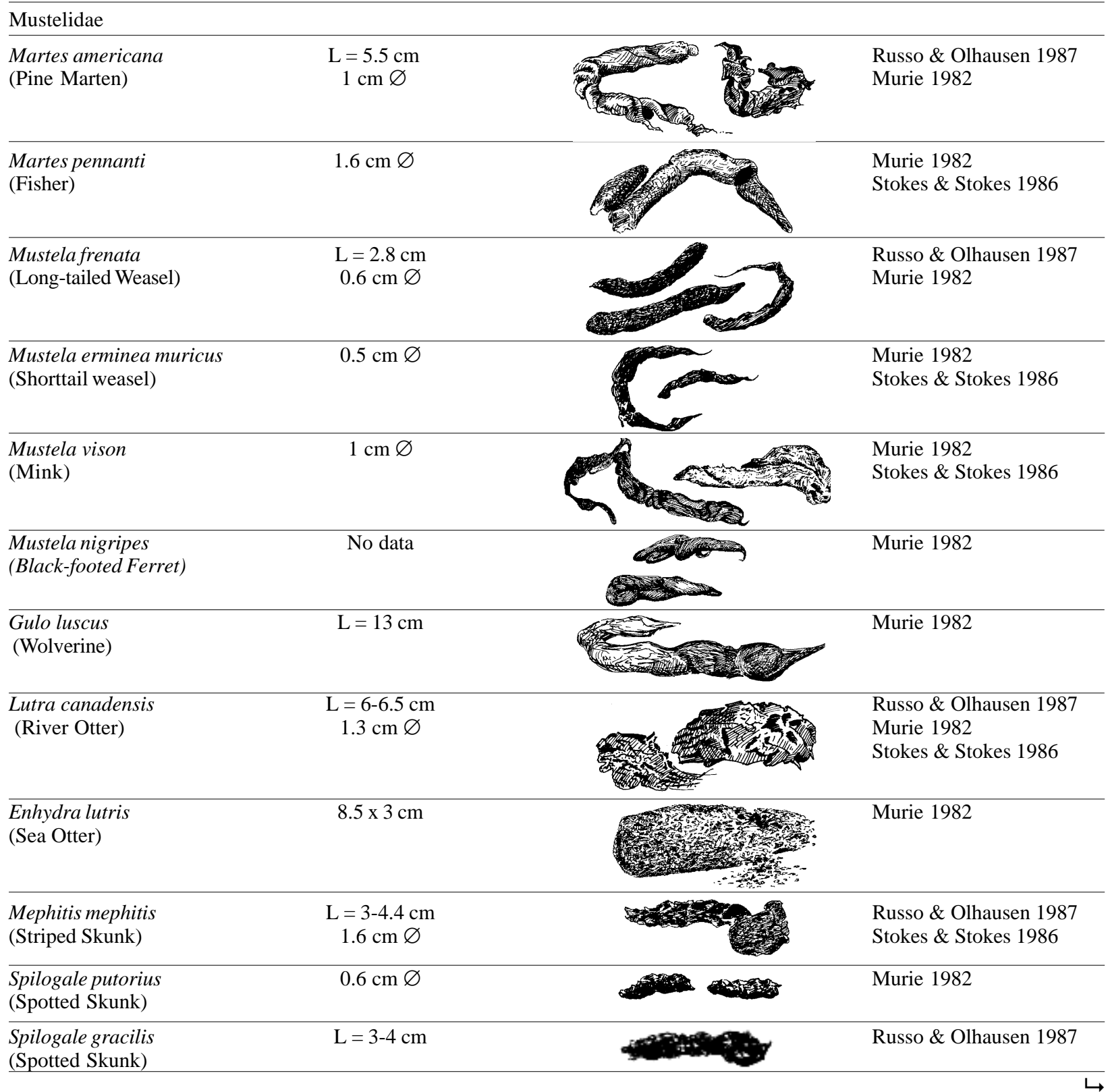




\begin{tabular}{|c|c|c|c|}
\hline Mammals' species & $\begin{array}{c}\text { Feces' measures } \\
\mathrm{Lx} \mathrm{W} \mathrm{cm} \\
\varnothing \mathrm{cm}\end{array}$ & Feces' shape & References \\
\hline $\begin{array}{l}\text { Taxidea taxus } \\
\text { (Badger) }\end{array}$ & $\begin{array}{c}\mathrm{L}=3.4-4.9 \mathrm{~cm} \\
1.6 \mathrm{~cm} \varnothing\end{array}$ & & $\begin{array}{l}\text { Russo \& Olhausen } 1987 \\
\text { Murie } 1982\end{array}$ \\
\hline \multicolumn{4}{|l|}{ Procyonidae } \\
\hline $\begin{array}{l}\text { Procyon lotor } \\
\text { (Raccoon) }\end{array}$ & $\begin{array}{c}\mathrm{L}=3-5 \mathrm{~cm} \\
2.5 \mathrm{~cm} \varnothing \\
\text { Comunity latrines }\end{array}$ & & $\begin{array}{l}\text { Russo \& Olhausen } 1987 \\
\text { Murie } 1982 \\
\text { Stokes \& Stokes } 1986 \\
\text { Page et al. } 2001\end{array}$ \\
\hline Nasua narica (Coati) & $\mathrm{L}=6.6 \mathrm{~cm}$ & & Murie 1982 \\
\hline \multicolumn{4}{|l|}{ Bassariscidae } \\
\hline $\begin{array}{l}\text { Bassariscus astutus } \\
\text { (Ringtail or Cacomistle) }\end{array}$ & $\mathrm{L}=7.6 \mathrm{~cm}$ & & Murie 1982 \\
\hline \multicolumn{4}{|l|}{ Ursidae } \\
\hline $\begin{array}{l}\text { Ursus americanus } \\
\text { (Black Bear) }\end{array}$ & $\begin{array}{l}\mathrm{L}=8-11 \mathrm{~cm} \\
5.7 \times 2.8 \mathrm{~cm}\end{array}$ & & $\begin{array}{l}\text { Russo \& Olhausen } 1987 \\
\text { Murie } 1982 \\
\text { Stokes \& Stokes } 1986\end{array}$ \\
\hline $\begin{array}{l}\text { Ursus horribilis } \\
\text { (Grizzly Bear) }\end{array}$ & $5.7 \mathrm{~cm} \varnothing$ & & Murie 1982 \\
\hline \multicolumn{4}{|l|}{ Canidae } \\
\hline $\begin{array}{l}\text { Canis lupus } \\
\text { (Gray Wolf) }\end{array}$ & $\begin{array}{c}\mathrm{L}=16 \mathrm{~cm} \\
>3 \mathrm{~cm} \varnothing \\
>2.5 \mathrm{~cm} \varnothing\end{array}$ & & $\begin{array}{l}\text { Murie } 1982 \\
\text { Weaver \& Fritts } 1979 \\
\text { Halfpenny \& Biesot } 1986\end{array}$ \\
\hline $\begin{array}{l}\text { Canis latrans } \\
\text { (Coyote) }\end{array}$ & $\begin{array}{l}5.5-8.8 \times 2 \mathrm{~cm} \\
\mathrm{~L}=10.6 \mathrm{~cm} \\
<3 \mathrm{~cm} \varnothing \\
1.8-2.5 \mathrm{~cm} \varnothing\end{array}$ & & $\begin{array}{l}\text { Russo \& Olhausen } 1987 \\
\text { Murie } 1982 \\
\text { Weaver \& Fritts } 1979 \\
\text { Stokes \& Stokes } 1986 \\
\text { Halfpenny \& Biesot } 1986\end{array}$ \\
\hline $\begin{array}{l}\text { Vulpes fulva } \\
\text { (Red Fox) }\end{array}$ & $\begin{array}{c}\mathrm{L}=5.8 \mathrm{~cm} \\
>1.8 \mathrm{~cm} \varnothing\end{array}$ & & $\begin{array}{l}\text { Murie } 1982 \\
\text { Halfpenny \& Biesot } 1986\end{array}$ \\
\hline $\begin{array}{l}\text { Vulpes macrotis } \\
\text { (San Joaquin Kit Fox) }\end{array}$ & $\mathrm{L}=3.1-6.9 \mathrm{~cm}$ & & $\begin{array}{l}\text { Russo \& Olhausen } 1987 \\
\text { Olhausen } 1987\end{array}$ \\
\hline $\begin{array}{l}\text { Urocyon cinereoargenteus } \\
\text { (Gray Fox) }\end{array}$ & $\begin{array}{c}5 \times 1 \mathrm{~cm} \\
\mathrm{~L}=6.4 \mathrm{~cm}\end{array}$ & & $\begin{array}{l}\text { Russo \& Olhausen } 1987 \\
\text { Murie } 1982\end{array}$ \\
\hline $\begin{array}{l}\text { Alopex lagopus } \\
\text { (Arctic Fox) }\end{array}$ & $\mathrm{L}=6.4 \mathrm{~cm}$ & & Murie 1982 \\
\hline
\end{tabular}




\begin{tabular}{|c|c|c|c|}
\hline Mammals' species & $\begin{array}{c}\text { Feces' measures } \\
\mathrm{Lx} \mathrm{W} \mathrm{cm} \\
\varnothing \mathrm{cm}\end{array}$ & Feces' shape & References \\
\hline \multicolumn{4}{|l|}{ Felidae } \\
\hline $\begin{array}{l}\text { Lynx rufus } \\
\text { (Bobcat or Wild cat) }\end{array}$ & $\begin{array}{c}\mathrm{L}=5-12.7 \mathrm{~cm} \\
\mathrm{~L}=10 \mathrm{~cm}\end{array}$ & & $\begin{array}{l}\text { Russo \& Olhausen } 1987 \\
\text { Murie } 1982 \\
\text { Stokes \& Stokes } 1986\end{array}$ \\
\hline $\begin{array}{l}\text { Puma concolor } \\
\text { (Mountain Lion } \\
\text { or Cougar or Puma) }\end{array}$ & $\begin{array}{c}\mathrm{L}=7.6-22.8 \mathrm{~cm} \\
13 \times 3.2 \mathrm{~cm} \\
>2.5 \mathrm{~cm} \varnothing\end{array}$ & & $\begin{array}{l}\text { Russo \& Olhausen } 1987 \\
\text { Murie } 1982 \\
\text { Johnson et al.1984 }\end{array}$ \\
\hline $\begin{array}{l}\text { Panthera onca } \\
\text { (Jaguar) }\end{array}$ & $\begin{array}{c}10.8 \times 2.2 \mathrm{~cm} \\
>2.5 \mathrm{~cm} \varnothing\end{array}$ & & $\begin{array}{l}\text { Murie } 1982 \\
\text { Johnson et al.1984 }\end{array}$ \\
\hline $\begin{array}{l}\text { Leopardus pardalis } \\
\text { (Ocelot) }\end{array}$ & $12.7 \times 1.6 \mathrm{~cm}$ & & Murie 1982 \\
\hline
\end{tabular}

\section{PINNIPEDIA}

\section{Otariidae}

Eumetopias jubata

(Northern Sea lion)

$\mathrm{L}=5-6.3 \mathrm{~cm}$

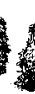

Murie 1982

UNGULATA (Super Order)

\section{ARTIOCADTYLA}

\section{Bovidae}

Ovis canadensis

(Bighorn Sheep)

\section{$\mathrm{L}=1.3-1.6 \mathrm{~cm}$}

Cakes: $8 \mathrm{~cm}$

$1-1.3 \times 0.6-0.9 \mathrm{~cm}$
Russo \& Olhausen 1987

Murie 1982

\begin{tabular}{|c|c|c|c|}
\hline $\begin{array}{l}\text { Oreamnos americanus } \\
\text { (Mountain Goat) }\end{array}$ & $\begin{array}{c}1 \times 0.4-0.6 \mathrm{~cm} \\
\text { Cakes: } \\
4.3 \times 2.3 \mathrm{~cm}\end{array}$ & Dry & Murie 1982 \\
\hline $\begin{array}{l}\text { Bison bison } \\
\text { (Bison or Buffalo) }\end{array}$ & $\begin{array}{l}\text { Cakes: } \\
30.5 \mathrm{~cm}\end{array}$ & & Murie 1982 \\
\hline $\begin{array}{l}\text { Ovibos moschatus } \\
\text { (Muskox) }\end{array}$ & $1 \times 0.6-1 \mathrm{~cm}$ & & Murie 1982 \\
\hline \multicolumn{4}{|l|}{ Antilocapridae } \\
\hline $\begin{array}{l}\text { Antilocapra americana } \\
\text { (Pronghorn Antelope) }\end{array}$ & $\begin{array}{c}\mathrm{L}=1.8 \mathrm{~cm} \\
\text { Cakes: } 4 \mathrm{x} \\
0.6-1.8 \\
\text { x } 0.8-1 \mathrm{~cm}\end{array}$ & & $\begin{array}{l}\text { Russo \& Olhausen } 1987 \\
\text { Murie } 1982\end{array}$ \\
\hline
\end{tabular}




\begin{tabular}{|c|c|c|c|}
\hline Mammals' species & $\begin{array}{c}\text { Feces' measures } \\
\text { Lx W cm } \\
\varnothing \mathrm{cm}\end{array}$ & Feces' shape & References \\
\hline \multicolumn{4}{|l|}{ Cervidae } \\
\hline $\begin{array}{l}\text { Odocoileus hemionus } \\
\text { (Mule Deer) }\end{array}$ & $\begin{array}{c}\mathrm{L}=1.2-1.8 \mathrm{~cm} \\
\text { Cakes: } 6.7 \mathrm{~cm} \\
0.6-1.8 \times 0.6-1.5 \mathrm{~cm}\end{array}$ & Dry & $\begin{array}{l}\text { Russo \& Olhausen } 1987 \\
\text { Murie } 1982\end{array}$ \\
\hline $\begin{array}{l}\text { Odocoileus virginianus } \\
\text { (White-tailed Deer } \\
\text { or Flag-tail) }\end{array}$ & $\begin{array}{c}\mathrm{L}=1.2-2.8 \mathrm{~cm} \\
\text { Cakes: } 4.8 \mathrm{~cm} \\
0.8-1.8 \times 1-1.8 \mathrm{~cm}\end{array}$ & Dry & $\begin{array}{l}\text { Russo \& Olhausen } 1987 \\
\text { Murie } 1982\end{array}$ \\
\hline $\begin{array}{l}\text { Cervus canadensis } \\
\text { (Wapiti or } \\
\text { Canadian Elk or Elk) }\end{array}$ & $\begin{array}{c}\mathrm{L}=1.8-3.5 \mathrm{~cm} \\
\text { Cakes: } 11 \mathrm{~cm} \\
1.7-2.5 \times 1.2-1.5 \mathrm{~cm}\end{array}$ & Dry & $\begin{array}{l}\text { Russo \& Olhausen } 1987 \\
\text { Murie } 1982\end{array}$ \\
\hline $\begin{array}{l}\text { Alces alces } \\
\text { (Moose) }\end{array}$ & $\begin{array}{c}2-3.4 \\
\times 1.5-1.8 \mathrm{~cm}\end{array}$ & & $\begin{array}{l}\text { Murie } 1982 \\
\text { Stokes \& Stokes } 1986\end{array}$ \\
\hline $\begin{array}{l}\text { Rangifer caribou } \\
\text { (Caribou or Reindeer) }\end{array}$ & $\begin{array}{c}0.7-0.9 \\
\text { x } 0.4-0.8 \mathrm{~cm} \\
\text { Cakes: } 5.5 \text { x } 3 \mathrm{~cm}\end{array}$ & & Murie 1982 \\
\hline \multicolumn{4}{|l|}{ Tayassuidae } \\
\hline $\begin{array}{l}\text { Pecari angulatus } \\
\text { (Peccary) }\end{array}$ & $1.2-3 \times 1.4 \mathrm{~cm}$ & & Murie 1982 \\
\hline
\end{tabular}

TABLE III

Feces' measures and shapes from Europe mammals

\begin{tabular}{|c|c|c|}
\hline & Feces' measur & \\
\hline Mammals' species & $\begin{array}{c}\mathrm{Lx} W \mathrm{~cm} \\
\varnothing \mathrm{cm}\end{array}$ & Feces' shape \\
\hline
\end{tabular}

\section{INSECTIVORA}

Erinaceus europaeus

(Hedgehogs)

$3-4 \times 0.8-1 \mathrm{~cm}$

\section{LAGOMORPHA}

Lepus capensis

(Hare)

$1.5-2 \mathrm{~cm} \varnothing$

Oryctolagus cuniculus

$1 \mathrm{~cm} \varnothing$

(Old world rabbit or

domestic rabbit) 
Mammals' species

Feces' measures

$\mathrm{L}$ x W cm

Feces' shape

$\varnothing \mathrm{cm}$

\section{RODENTIA}

\section{Sciuridae}

Sciurus vulgaris

(Tree squirrels)

$0.5-0.8 \times 0.5-0.6 \mathrm{~cm}$

Castoridae

Castor fiber

(European Beaver)

$2-4 \times 2 \mathrm{~cm}$

\section{Muridae}

Ondatra zibethicus

(Muskrat)

Arvicola amphibius

(Water voles)

Microtus arvalis

(Voles, Meadow mice)

Lemmus lemmus $0.6 \times 0.3 \mathrm{~cm}$

(True Lemmings)

Rattus norvergicus 1.7 x $0.6 \mathrm{~cm}$

(Norway Rat)

$$
1.2-1.4 \times 0.5 \mathrm{~cm}
$$

$0.7-1 \times 0.3-0.4 \mathrm{~cm}$

$0.6-0.7 \times 0.2-0.3 \mathrm{~cm}$

Rattus rattus

(Black Rat)

$1 \times 0.2-0.3 \mathrm{~cm}$

Mus musculus

(Mice)

$0.6 \times 0.2-0.25 \mathrm{~cm}$

Capromyidae

Myocastor coypus

(Nutria, Coypu)

$$
2-3 \times 1 \mathrm{~cm}
$$

\section{CARNÍVORA}

\section{Canidae}

Vulpes vulpes

(Red Fox)

$8-10 \times 2 \mathrm{~cm}$

Canis lupus

(Wolf)

$10-15 \times 2.5-3 \mathrm{~cm}$

Ursidae

Ursus horribilis

(Grizzly bear)

$6 \mathrm{~cm} \varnothing$

Mustelidae

Meles meles

(Old World Badger)

Martes martes

(Martens, Fisher, Sable)

No data

$8-10 \times 1.2 \mathrm{~cm}$

No data

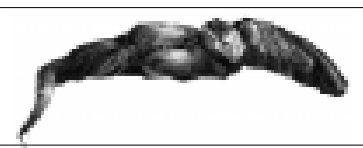




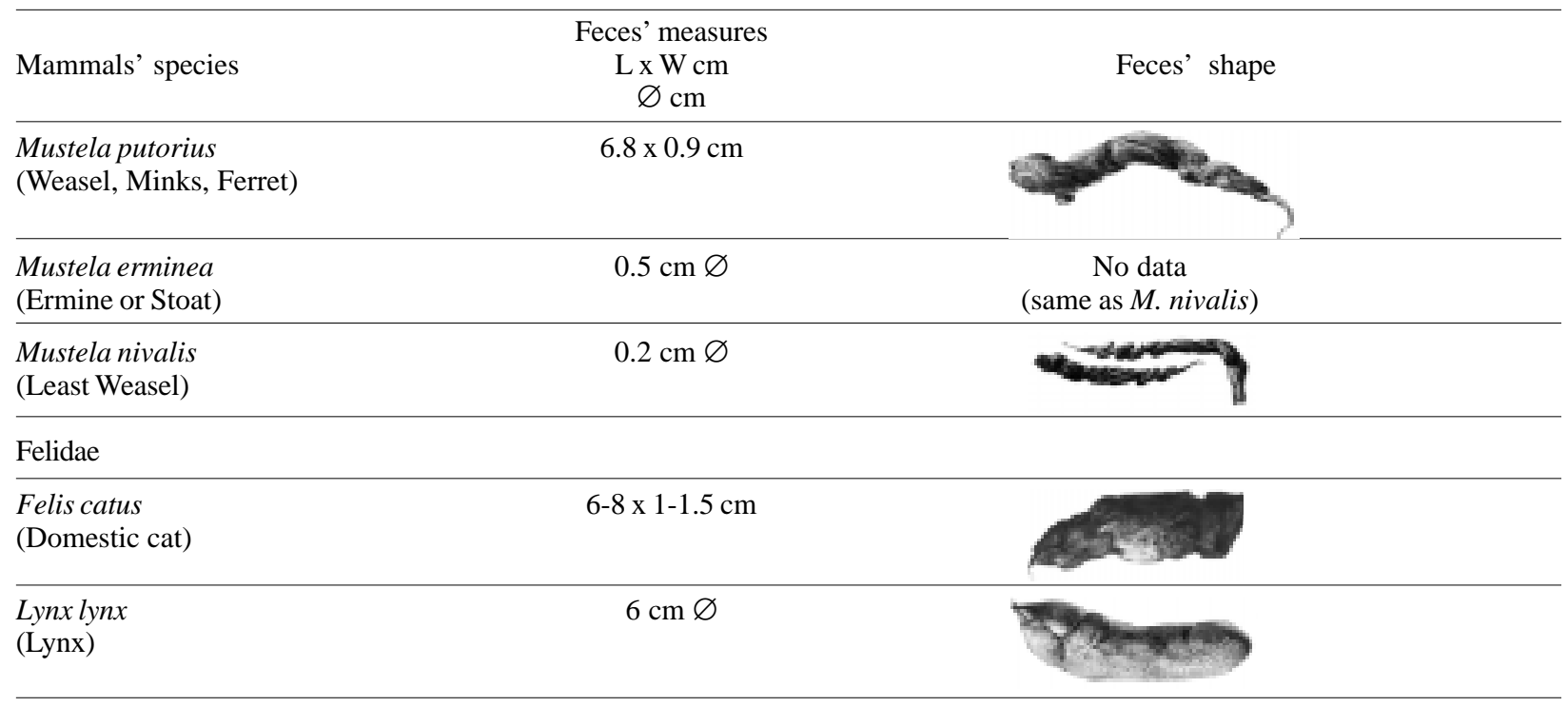

UNGULATA (Grand order)

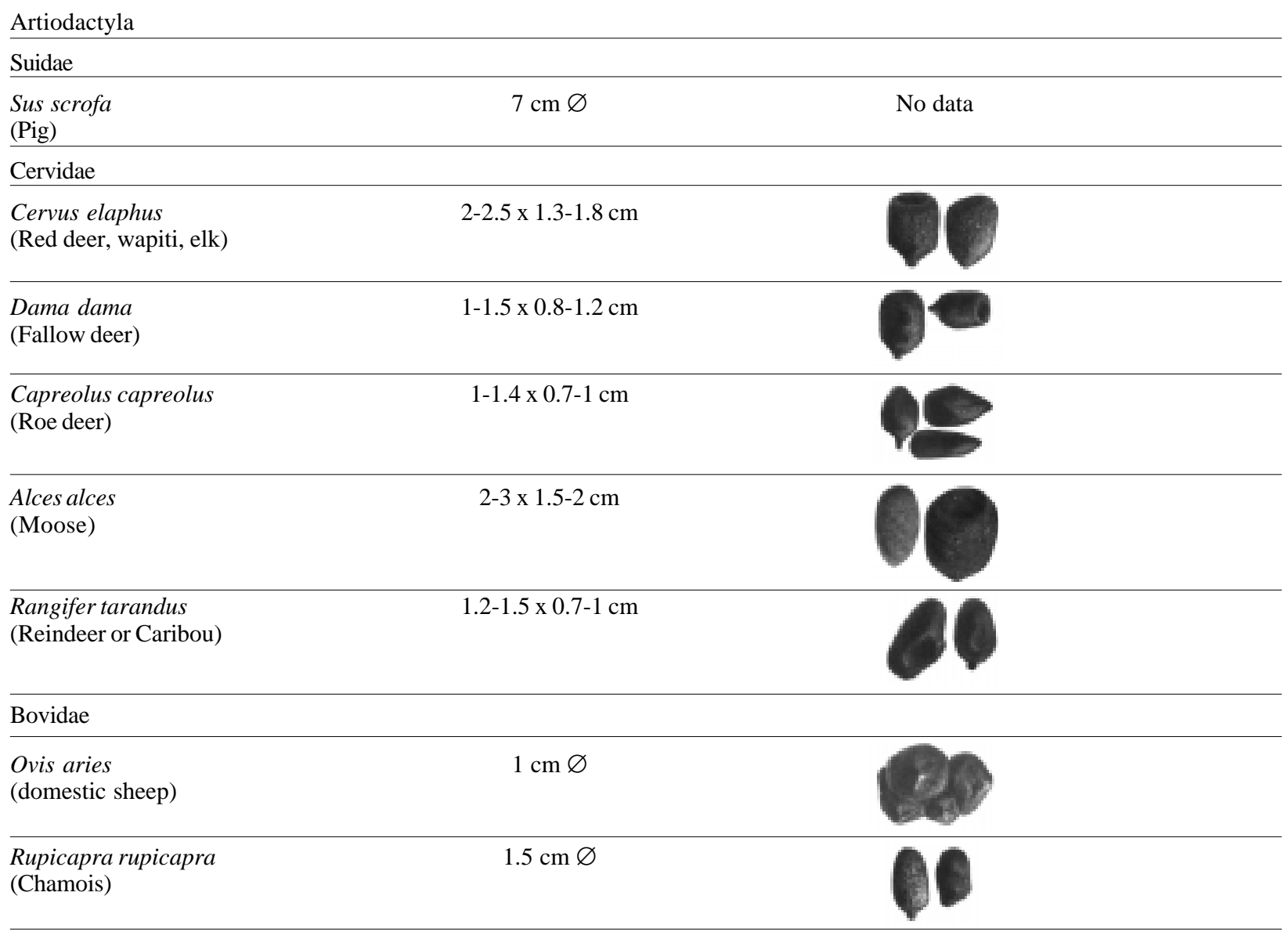

Based on Bang \& Dahlström (1975). 
TABELA IV

Feces' measures from Northeastern Brazilian Mammals

Mammals' Species

Feces' length

$\mathrm{cm}$
Feces' diameter $\mathrm{cm}$

\section{XENARTHRA}

Dasypodidae

Dasypus novemcinctus (nine-banded armadillo)

1.1-3.7

$1.1-2.8(\mathrm{n}=15)$

Myrmecophagidae

Tamandua tetradactyla (southern tamanduá)

$1.8-8.1$

$1.5-2.5(\mathrm{n}=28)$

RODENTIA

Caviidae

Kerodon rupestris (Mocó or rocky cavy)

Galea spixii (Preá)

$0.9-1.7$

$0.5-0.8$

$0.4-0.6(\mathrm{n}=49)$

Echymyidae

Trichomys apereoides (Rabudo)

Muridae (Sigmodontinae)

Oryzomys subflavus

$0.1-0.2(n=20)$

PRIMATA

Alouatta caraya (black howler monkey)

$1.1-4.1$

$1.9-2.6(n=4)$

\section{CARNIVORA}

\section{CANIDAE}

Cerdocyon thous (Crab-eating fox)

$1.5-10.8$

$1.7-2.3(n=9)$

FELIDAE

Panthera onca (jaguar)

2.6-11.2

$3.7-6.1$

2.4-2.8 $(\mathrm{n}=14)$

Puma concolor (puma or cougar)

3.1-3.4

Leopardus tigrinus (little spotted cat)

$2.2-3.2(\mathrm{n}=4)$

$1.5-1.5(\mathrm{n}=4)$

\section{UNGULATA}

Artiodactyla

\section{Cervidae}

Mazama gouazoubira (Brocket deer)

Mazama americana (Red Brocket deer)

$0.9-5.1$

$0.7-1.0$

$0.5-2.8(\mathrm{n}=25)$

Tayassuidae

Tayassu tajacu (Collared peccary)

$0.9-2.4$

$0.7-0.92(\mathrm{n}=15)$

Tayassu pecari (White-lipped peccary)

$0.9-2.3$

$1.2-2.2(\mathrm{n}=39)$

$0.8-1.3(\mathrm{n}=20)$ 